\title{
Fish Consumption Advisory Programs: Opportunities and Challenges for the Protection of Human Health in Canada and the United States
}

\author{
$\underline{\text { Rachael King }}{ }^{1}, \underline{\text { Beth Polidoro }}^{1}, \underline{\text { Karen H. Watanabe }}^{1}, \underline{\text { Trevor }}^{2}$ \\ Avery $^{2}$ \\ ${ }^{1}$ Arizona State University West, New College of Interdisciplinary Arts and Sciences, Glendale, AZ \\ ${ }^{2}$ Acadia University, Department of Biology, Wolfville, NS, Canada \\ https://doi.org/10.38126/ISPG190105 \\ Corresponding author: rachaelking722@gmail.com \\ Keywords: environmental policy; fisheries; environmental justice; aquatic toxicology
}

\begin{abstract}
Executive Summary: Fish consumption advisories provide valuable information on the protection of human health from contaminated fish consumption, yet are rarely conducted comprehensively nor communicated widely. Environmental policies that fail to adequately develop and implement fish consumption advisory programs are largely to blame. This policy analysis delves into the strengths and weaknesses of current fish consumption advisory programs in the United States and Canada. To compare between these countries, fish consumption advisory programs were broadly described across all 50 US states and 13 Canadian provinces/territories. Two case studies were chosen to provide a more detailed look into the complexities of fish consumption advisory programs (Arizona and Nova Scotia). It is apparent from this research that fish consumption advisory programs and policies do not comprehensively address human health and environmental justice concerns in either country suggesting policy changes are necessary. Opportunities for and barriers to regulatory change in both countries were identified, and suggestions on sharing strong policies were provided. Finally, international frameworks aimed at improving fish consumption advisory programs were explored, mainly those used by the European Union. Environmental justice and human health concerns will only increase given changing environments and emerging toxicological issues; therefore, increased focus on fish consumption advisory programs is warranted. This focus should consider policy change in particular because it can codify human health and environmental justice protections upon which stronger fish consumption advisory programs can be built.
\end{abstract}

\section{Introduction}

Fishes are commonly caught and consumed in the United States and Canada, with $20 \%$ of US adults consuming seafood at least twice per week and over 3.2 million recreational anglers in Canada (Terry et al. 2018; "Survey of Recreational Fishing in Canada, 2015" 2019). Fish consumption includes both commercially and recreationally caught fishes where one in ten Americans (10\%) and about $12 \%$ of the
Canadian population fishes recreationally ("Fishing License Renewals and Angler Lifestyles" 2016; "Survey of Recreational Fishing in Canada, 2015" 2019). Although fish provide a good source of local protein, consuming large amounts of recreationally caught fishes may present threats to human health due to bioaccumulation of chemical contaminants in fish tissue. Aquatic habitats can become contaminated with chemicals, most frequently heavy 
metals, organic contaminants, and legacy pollutants. These contaminants can accumulate in fishes through gills, skin, or through consuming contaminated organisms in a process called bioaccumulation ("Guidance for Assessing Chemical Contaminant Data for Use in Fish Advisories" 1995). When humans eat contaminated fishes, as is often the case in recreational fishing, contaminants can be metabolized and/or sequestered in various physiological pathways potentially leading to health risks including endocrine disruption, cancer, neurotoxicity, and reproductive and developmental toxicity ("Guidance for Assessing Chemical Contaminant Data for Use in Fish Advisories" 1995). Therefore, fish consumption advisories are commonly developed and released in the US and Canada (and most other countries) to warn consumers of contaminants present in fish tissue and provide guidelines on how much fish is safe to eat.

Fish consumption advisory programs are effective in reducing the consumption of fishes with elevated contaminants by carrying out routine testing of fish tissues (Tilden et al. 1997); however, certain population segments may not be aware of advisories due to barriers such as language or literacy, or even lack of knowledge of such advisories. For example, in a survey of women in the Sacramento-San Joaquin Delta, $56 \%$ of Caucasian women were aware of a specific fish consumption advisory, compared to $10 \%$ of Hmong and $17 \%$ of Vietnamese women (Silver et al. 2007). As a result, almost a third (29\%) of women studied exceeded the Environmental Protection Agency/Federal Drug Administration (EPA/FDA) joint fish consumption advisory limit for recreational and commercial fish consumption, with non-Caucasian women exceeding the limits in greater proportions resulting in disproportionate effects on low-income, non-Caucasian groups (Silver et al. 2007). Disproportionate effects can lead to serious health conditions in certain populations, thereby affecting both public health and environmental justice at increasingly large scales.

We address fish consumption advisory programs through: 1) comparison of state/provincial/

territorial and federal programs across the US and Canada, and 2) case study comparison of programs from a selected state and province. The public health focus is upon recreational fishers who may consume contaminated fishes. The environmental justice focus is on low-income and minority groups that may be unequally affected by consuming contaminated fishes and is intended to highlight the need for inexpensive, healthy protein sources. Often the cheapest and most accessible protein source for already vulnerable communities is recreationally caught fishes, which in turn are often chemically contaminated. Policy changes that provide consumers with direct and accurate information on the health risks of consuming contaminated fish would help reveal the need for other policies directed at providing marginalized communities with healthy protein sources. Providing up-to-date and adequate information on contaminants in fish and the inherent human health risks to consumers of recreationally caught fishes are crucial steps in recognizing the underlying disparities in the status quo. Therefore, many of the proposed improvements to fish consumption advisory policy will focus on the need for effective risk communication (Connelly and Knuth 1998; LePrevost et al. 2013).

\section{Methods}

To understand fish consumption advisory programs across the US and Canada, publicly available information on fish consumption advisory programs in all fifty US states and thirteen Canadian provinces/territories were compiled and reviewed. Arizona and Nova Scotia were selected as case studies based on greater access to local information. In reviewing fish consumption advisory programs, opportunities and challenges to improving such programs were noted and a comparison and contrast was done of both existing fish consumption advisory programs and opportunities and challenges to program improvement was conducted between the countries.

\section{Results}

i. US recreational fisheries monitoring programs

To create fish consumption advisories, fish tissue monitoring must be regularly and systematically conducted across contaminated sites to identify levels of contaminants that may be harmful to human health. In the US, the Environmental 
Protection Agency's (EPA) Clean Water Act sets guidelines for states to monitor surface water quality (Federal Pollution Control Act 2002). When implemented at the state level, the Clean Water Act allows state environmental or public health agencies to develop and implement their own water quality guidelines and monitoring programs, many of which include monitoring programs for recreationally caught fishes (Federal Water Pollution Control Act 2002). Although state programs must be approved by the EPA, there is little consistency between states in the frequency and type of monitoring conducted in surface waters, especially among states that support recreational fisheries.

The only strict requirement from the US Clean Water Act regarding monitoring of contaminants in fishes, is for each state to monitor mercury in fish tissue in waters with a designated use of fishing (Federal Pollution Control Act 2002). However, states are not required to set fishing as a designated use for their water bodies ("Water Quality Standards Handbook" 2012). If states have fishing as a designated use for their water bodies, the EPA provides guidance for the development of fish consumption advisory programs ("Guidance for Assessing Chemical Contaminant Data for Use in Fish Advisories" 1995). Unfortunately, the guidance documents are a recommendation only and the EPA has not developed any legislation mandating fish consumption advisory programs.

Recreational fish contaminant monitoring programs in the US vary considerably by state (Appendix A). There is no comprehensive requirement for all recreationally fished waters to be designated with this use, no federal requirements for monitoring contaminants other than mercury, and no federal requirement for creating fish consumption advisory programs. Discrepancies in monitoring the scope of recreationally caught fish consumption advisories between US states leads to unequal human health protections across the nation. Such discrepancies include the range of contaminants monitored in fish tissues, the number of fish monitored per year, and the number of water bodies monitored per year (Appendix A). States such as Alabama conduct much more extensive monitoring than states like Nevada and are consequently better able to warn citizens of contaminants in recreationally caught fishes (Appendix A).

ii. Arizona case study: fish consumption advisory program

Arizona is a dry and land-locked state with few natural water bodies. Most water bodies supporting recreational fisheries are man-made including large, dammed lakes. Many major cities, including Phoenix and Tucson, support Community Fishing Programs in urban lakes and ponds, providing an opportunity for urban dwellers to partake in recreational fishing without travelling long distances to other water bodies ("2020 Community Fishing Guidebook," n.d.). The urban lakes and ponds are created either by digging deep holes below groundwater levels or by diverting water from aquifers running through urban areas.

A five-year study of surface water quality in waters supporting the Community Fishing Program in metro-Phoenix revealed that despite the vast majority (all but two) of urban lakes and ponds not having a designated fishing use under the Clean Water Act, more than thirty of the thirty-eight community fishing waters support recreational fishing (Lucas and Polidoro 2019; Pulford et al. 2017). As a result, these waters are not monitored by the Arizona Department of Environmental Quality (ADEQ) for contaminants because they are not considered "waters of the US" (Condon and Jones 2017). Arizona requires monitoring of mercury in fish tissue for all waters designated as recreational fishing use, but without applying this designated use to urban lakes and ponds, monitoring activities are largely non-existent. Thus, comprehensive monitoring of contaminants in recreationally caught fishes across metro-Phoenix is limited and excluded from the state fish consumption advisory program. With an annual license fee of only $\$ 24$, urban recreational fishing is an extremely popular, low-cost and growing activity (License n.d.). Furthermore, as nearly $60 \%$ of urban residents in metro-Phoenix report eating the fishes they catch (Pulford et al. 2017), this presents a potential human health issue if fishes are not being monitored for contaminants in pollution-rich, urban settings. Additionally, this presents an environmental justice issue as urban lakes and ponds tend to be placed in already 
vulnerable communities. Environmental justice is defined by the EPA as "the fair treatment and meaningful involvement of all people regardless of race, color, national origin, or income, with respect to the development, implementation, and enforcement of environmental laws, regulations, and policies" ("Environmental Justice" n.d.). The placement of these lakes and ponds combined with the low cost of community fishing licenses incentivizes the use of fishes as a primary protein source by vulnerable groups, thus increasing the negative health impacts in these communities.

Larger artificial and natural lakes in Arizona require monitoring of different contaminants based on their designated use, and do not require monitoring without a designated use. Although any lake with a designation requires monitoring every three years under the EPA's triennial water quality review process, the actual monitoring of such water bodies is limited. For example, fish tissues from waters designated for fishing are monitored infrequently for mercury alone. Many lakes will only be monitored approximately once every ten years due to financial and capacity limits inside ADEQ. Such infrequent monitoring is evidenced by triennial water quality review reports that fail to list major recreational fisheries, such as that which occurs in Lake Mead (Condon and Jones 2017). Long periods between monitoring increases the safety concerns of consuming fish from water bodies with known contaminants. Importantly, even stocked fishes can accumulate contaminants present in surface waters in a matter of weeks (Lucas and Polidoro 2019), posing human health risks.

Further adding to health concerns are the additional bioaccumulative contaminants that may be present in fish tissues but are not monitored like mercury (Condon and Jones 2017). ADEQ's public searchable database shows fish tissue monitoring for a handful of other contaminants, including chlordane and dieldrin, in isolated instances ("Search Water Quality Data" n.d.), but these contaminants do not appear in any monitoring methods or protocols released by ADEQ. Indeed, contaminants in fishes from urban lakes and ponds show pesticides, PCBs and potentially aluminum may pose significant health risks to urban anglers (Lucas and Polidoro 2019;
Pulford et al. 2017). Without comprehensive and regular monitoring for a suite of contaminants, especially in relation to urban lakes and ponds, human health is at increased risk from contaminated fish consumption.

Unfortunately, fish consumption advisories, when available, are only posted online (on the ADEQ and Arizona Game and Fish websites) and/or at select fishing locations. When fish consumption advisories are posted at fishing locations, they tend to be posted at fish cleaning stations, meaning recreational anglers already caught fish before observing advisories. Providing advisories broadly in multiple formats including flyers or at boat ramps to advise anglers prior to fishing, will increase awareness and their intended effectiveness. However, current limitations on the posting locations and formats of advisories are exacerbated by advisories being posted only in English. This contributes to the environmental justice issue surrounding contaminated fish consumption as non-English-speaking groups may be unable to understand posted advisories. Fish consumption advisories need to target populations, such as low-income communities and non-native English speakers, who are exposed to more chemical contaminants due to their dependence on fishes as their primary protein source.

\section{iii. Canadian recreational fisheries monitoring} programs

In Canada, there is no federal policy equivalent to the Clean Water Act in the US; no legislation requires ongoing water or fish quality monitoring across the country. Fisheries and Oceans Canada (DFO) is the only federal agency with any jurisdiction for fish tissue contaminant monitoring in Canada, and this agency evaluates saltwater fishes and often includes diadromous species ("Survey of Recreational Fishing in Canada, 2015" 2019). With the exception of Nunavut, all other provincial and territorial governments have fish consumption advisory programs where some tissues may be monitored. However, these programs are not mandated or required by law and are limited to freshwater fishes, which are provincially managed ("Survey of Recreational Fishing in Canada, 2015” 2019). 
Additionally, Canada does not provide federal recommendations for fish contaminant monitoring across the country. Where the US EPA provides recommendations for the creation of state fish consumption advisory programs, DFO provides no guidance for regional programs. Similarly, Environment and Climate Change Canada, a federal agency, provides no guidance to provincial or territorial governments on forming environmental oversight and policy because its jurisdiction is separate from provinces and territories.

While Health Canada does provide some guidelines for levels of contaminants in fish tissue that may negatively impact human health (e.g. for mercury; Mercury: Your Health and the Environment 2004), these guidelines are not as comprehensive as those created by the US EPA. Therefore, with no federal requirements to monitor fish tissue contaminant levels and no federal recommendations on the formation or structure of fish consumption advisory programs, such programs vary considerably across Canada (Appendix B). An extreme case is Nunavut, which does not currently have a fish consumption advisory program despite suggestions it was adapting advisory programs from other territories as early as 2001 (M. E. Wood 2001).

Not having an advisory program presents an environmental justice concern. Approximately 84\% of Nunavut residents are Inuit, an Indigenous group that traditionally use fishes in ways that can increase their exposure to chemical contaminants ("Guidance for Assessing Chemical Contaminant Data for Use in Fish Advisories" 1995; "Nunavut FAQs" n.d.; Ponting 2007).

iv. Nova Scotia case study: Canadian fish consumption advisory programs

Nova Scotia has over 3,000 natural lakes and ponds within which approximately 65,000 anglers fished in 2018 (Fairclough 2019; "Wildlife and Birds of Nova Scotia" n.d.). The Nova Scotia Department of Aquaculture and Fisheries (NSDAF) is responsible for monitoring contaminants levels in fish tissue throughout the province to support fish consumption advisories (M. E. Wood 2001). NSDAF monitors fish tissue for PCBs and mercury, with active fish consumption advisories for both substances ("NS Fish Consumption Advisories" n.d.). Fish consumption advisories are released by the Nova Scotia Department of the Environment ("NS Fish Consumption Advisories" n.d.).

Chemical contamination appears to be relatively low in Nova Scotia, especially compared with Arizona. Arguably chemical pollution from mining, including gold, coal, salt, limestone, and gypsum, is of greatest concern because mining has been a mainstay of the economy for over a hundred years ("Nova Scotia Mining Operations (2018)" 2019). Mining operations, especially those for gold and coal, release a variety of contaminants into the environment. Because of concerns about contaminants in fishes resulting from mine tailings, the Historic Gold Mines Committee was established in 2005 with a Freshwater Working Group subcommittee established in 2006 to assess the degree of mercury and arsenic contamination in fishes was associated with historical gold mines (LeBlanc and Halfyard 2010). Brook trout, smallmouth bass, white perch, and yellow perch associated with mine tailings exceeded by greater than $30 \%$ the Canadian human health guideline for consumption of mercury in fishes (LeBlanc and Halfyard 2010). White suckers and yellow perch associated with mine tailings additionally exceeded the Canadian human health guideline for arsenic consumption in fishes (LeBlanc and Halfyard 2010). These levels warrant including mercury in fishes associated with mine tailings into fish consumption advisories for Nova Scotia (LeBlanc and Halfyard 2010).

Unfortunately, there is no routine testing of contaminants in fish tissues in Nova Scotia; rather tests are conducted when there is likely to be contamination of concern and a need for new or revised fish consumption advisories (as seen above with the Historic Gold Mines Committee). Therefore, while the fish consumption advisory program in Nova Scotia monitors for more contaminants than Arizona's program, both programs suffer from a lack of routine monitoring to help protect human health from the consumption of contaminated fishes. 


\section{Discussion}

i. Comparisons of protections of public health and environmental justice in the US and Canada

Currently, in the US, both public health and environmental justice vary in their levels of protection across states. Overall, the Clean Water Act does not appear to provide strict enough guidelines to protect human health and environmental justice as it relates to consumption of recreationally caught fishes. Only a few studies have examined human health risks from fish consumption for a broad range of contaminants (Lewis et al. 2002; Watanabe et al. 2003; Lucas and Polidoro 2019), which are sporadic and subject to individual research team resources while the protection of public health requires regular fish tissue monitoring and health risk analysis. This point is demonstrated in Arizona, which follows the Clean Water Act, yet has not expanded its fish consumption advisory program to cover urban fishers that are exposed to levels of mercury and aluminum potentially exceeding the EPA recommended thresholds for those metals (Lucas and Polidoro 2019). Even in states that have more extensive fish consumption advisory programs, environmental justice appears to remain an issue. For example, in California, women in the San-Joaquin Delta region are more likely to consume recreationally caught fishes with relatively higher contaminant concentrations or consuming more fish in general thus increasing exposure if they are non-Caucasian and if they belong to a lower income group (Silver et al. 2007) despite California monitoring for mercury, PCBs, DDT, dieldrin, PBDEs, chlordane, selenium, and toxaphene in fishes. The imbalance between health protection and environmental justice in California apparently does not stem from monitoring efforts, rather risk communication may fail to reach vulnerable groups (Veres 1995). Because fish consumption advisories are posted only in English or not posted in accessible places, as in Arizona, vulnerable groups may be unintentionally excluded from protection efforts and risk greater harm (Silver et al. 2007).

Unfortunately, human health and environmental justice are also inadequately protected in Canada. Canada does not have federal monitoring requirements like in the Clean Water Act, leading to a potentially greater failure to protect human health and environmental justice across the country. While some provinces, such as Ontario, have chosen to create extensive fish consumption advisory programs, there is no requirement that any province monitor for any contaminants in recreationally caught fishes. Nunavut does not have a fish consumption advisory program putting federal requirements in sharp relief.

\section{ii. Opportunities and challenges for policy changes in} the US

Improving human health and environmental justice protections in the US and Canada at the state or provincial/territorial level and at the federal level are needed. At the US Federal level, there are many opportunities for policy changes principally driven by academic researchers and government agencies to support environmental justice and improvements in human health protections. For example, the National Environmental Policy Act (NEPA) has an executive order to address environmental justice in minority and low-income populations ("Summary of Executive Order 12898 - Federal Actions to Address Environmental Justice in Minority Populations and Low-Income Populations" n.d.). Additionally, the EPA recommends reporting distributions of contamination among different ethnic and economic groups ("Guidance for Assessing Chemical Contaminant Data for Use in Fish Advisories" 1995). Federal policy changes would provide widespread improvements to both human health and environmental justice protections, but are more difficult to pass and, thus, are less likely to occur. In comparison, policy changes may be easier to implement at the state level because states are federally recommended to develop fish consumption advisory programs and improvements are directed at local public health and environmental justice concerns. For example, in Arizona, ADEQ has the jurisdiction to increase its fish tissue monitoring program by designating any water within the state for monitoring (ADEQ 2019, pers. comm., Feb. 20). Therefore, ADEQ could expand its monitoring program to encompass urban lakes and ponds and test for more contaminants in fish tissue; impediments to these changes appear to be funding and associated staff capacity. Resulting from our study, a bill was introduced to the Arizona State 
Legislature in January 2020 and January 2021 (Appendix C) with the goal to help improve water quality and recreational fisheries contaminants monitoring throughout the state, including urban waters, by increasing the mandate and capacity of ADEQ.

The main challenge to widespread and consistent implementation of more comprehensive contaminant monitoring programs for surface waters and recreational fisheries in the US, including implementation of fish consumption advisories, lies with the lack of strict requirements for fish contaminant monitoring under the Clean Water Act. No federal legislation currently exists in the US that requires monitoring of specific named contaminants in water or fish tissue allowing states to prioritize, based on budget, capacity, or politics, how and when to monitor for contaminants. These actions typically result in increased human health and environmental justice concerns and make widespread and comprehensive policy changes difficult. Federal directives would help steer state policies.

An important consideration, and challenge, in policy changes at the federal or state level is remediation of persistent or legacy contaminants, which may not decrease in a reasonable time without human intervention. These contaminants pose a continual threat to human health and environmental justice. While preventing or minimizing contaminants is an important step in protecting human health, existing persistent or legacy contaminants require remediation, especially in urban areas that support recreational fishing. For example, the Duwamish River in Seattle, WA was declared an EPA superfund site in 2001 based on major contamination caused by years of industrial activity along the river ("Lower Duwamish Waterway Seattle, WA" n.d.). The Duwamish River supports fishing by many vulnerable communities that live along the river, which lead to increased human health problems in these communities; this, in turn, prompted the large-scale remediation action ("Lower Duwamish Waterway Seattle, WA" n.d.). In this case, the ecosystem rebounded well, but such remediation methods are quite costly and not always realistic.
Challenges to fish consumption advisory program policy in Arizona likely reflect similar barriers to improving fish consumption advisories across all US states. Arizona is a conservative state and environmental protection has become synonymous with the removal of power for much of the conservative party (Hamilton 2010). However, even with recent policy changes that led to improved legislation, increased monitoring, and a more rigorous fish consumption advisory program in Arizona, vulnerable communities are often unreceptive to fish consumption advisories, especially if no alternative protein sources are provided to replace contaminated fishes (Tan, Ujihara, and Hendrickson 2011).

Arizona has large groups of retirees that fish recreationally, and large Hispanic and Indigenous communities, within which reluctance to comply with fish consumption advisories may be especially pronounced (Tan, Ujihara, and Hendrickson 2011). This sentiment is underscored: "Fishermen disregard the advice [of fish consumption advisories] for various reasons... they are skeptical when advice contradicts long-held beliefs and attitudes about fishing, they think the information does not apply to them or the location where they fish, they rely on sensory cues to judge safety, or they do not trust the government source of information" (Tan, Ujihara, and Hendrickson 2011). Older individuals across the US are both more likely to fish and more likely to reliably renew their fishing licenses ("Fishing License Renewals and Angler Lifestyles" 2016). Within many Hispanic communities, recreationally caught fishes may serve as a primary protein source; therefore, the general reluctance to follow fish consumption advisories can be related to a lack of other low-cost alternatives (Silver et al. 2007; Terry et al. 2018). Additionally, Indigenous communities have historically been disproportionately impacted by recreational fish contamination as cultural traditions may often require the consumption of fishes (Roe 2003). Generally, if an advisory contradicts personal beliefs around fish consumption, individuals tend to side with personal beliefs (Tan, Ujihara, and Hendrickson 2011). Therefore, effective communication requires 
additional efforts to address both the technical information related to fish contamination and the personal beliefs common across target demographics (Veres 1995). These actions often require community meetings to identify commonly held myths surrounding fish consumption and involve the target demographic in conversations on risk assessment (Veres 1995). Two simple solutions to better communicating fish consumption advisories in Arizona would be to move fish consumption advisory postings to boat ramps (rather than cleaning stations) and post advisories in both Spanish and English so that fishers both see the advisories before catching fishes, and so Hispanic individuals are able to read advisories. This risk communication issue is likely widespread across many states; the Great Lakes states have similar issues in addressing target demographics, such as women and non-Caucasian groups, with fish consumption advisories (Tilden et al. 1997).

\section{iii. Opportunities and challenges for policy changes in} Canada

Opportunities for policy improvement in Canada may be more urgent than in the US, as Canada lacks the federal legislation that provides even basic guidelines for fish consumption advisory programs. One important opportunity in Canada is that Prime Minister Justin Trudeau's administration has made a positive difference in protecting the environment following almost a decade of conservative rule that removed many environmental protections (Olive 2019). Similarly to the US, independent research support exists in Canada and academic researchers contribute greatly to information on human health and environmental justice concerns arising from contaminated fish consumption. For example, Acadia University in Wolfville, Nova Scotia is currently (as of March 2021) conducting fish contaminant monitoring across the province, primarily for recreationally caught coastal fishes to use as a current coastal baseline (Pomerleau 2019). These results will be provided to the NSDFA and DFO. Marine contaminant level baselines are important, but historically few exist (Romo et al. 2019). Conversely, monitoring contaminants in freshwater fishes and their effects on fish health in Nova Scotia is relatively more widespread, especially for mercury (e.g. Wyn et al. 2009; Batchelar et al. 2013).
Summaries of mercury based on national or regional international data exist and provide important, historical benchmarks for developing fish advisory programs (Depew et al. 2013; Kamman et al. 2005). Contaminant information provided by researchers will assist the official provincial monitoring program; most US states do not allow academic researchers to conduct official fish contaminant monitoring due to liability concerns. Environmental justice also is being addressed at the federal level in Canada, with proposed bills to enact environmental policies to counter concerns for negative effects of various impacts on Indigenous populations. For example, Bill C-69 states that the proposed Impact Assessment Act "sets out the factors to be taken into account in conducting an impact assessment, including the impacts on the rights of the Indigenous peoples of Canada" (Bill C-69 2019). Canadian federal opportunities appear similar to those in the US but have not yet been fully mandated or institutionalized.

In Canada, Nova Scotia highlights policy change opportunities to better protect human health and environmental justice. The Supreme Court of Nova Scotia recently overruled a decision to allow Alton Gas to continue an operation on the Shubenacadie River that would threaten the health and welfare of the Sipekne'katik First Nation (Tutton 2020). This recognition of the rights of Indigenous communities in Nova Scotia emphasizes the importance of considering environmental justice in policy decisions and shows provinces consider environmental justice in decision-making.

The largest impediment to policy change in Canada is the lack of an existing legislative template to use for improving fish consumption advisory programs. All federal policy changes must work their way through the relevant provincial and/or federal jurisdictions. Canada may find guidance in the US Clean Water Act for water and fish quality monitoring requirements, but this legislation would still have to be written and passed in Federal Parliament to improve fish consumption advisory programs at the federal level. Additionally, Canadian federalism provides various obstacles to implementing a version of the US Clean Water Act. Because the current system leaves environmental 
protection almost entirely up to the provinces, federal legislation would need to make clear the responsibilities of each province and require each province to develop its own fish consumption advisory program. In the US, states have the option to create a fish consumption advisory program, but some states, such as Hawaii, lack a state supported program. In Canada, because there is no federal agency with jurisdiction over freshwater fish contaminant monitoring, fish consumption advisory programs would have to be developed independently within each province to ensure the protection of public health.

Unfortunately, the Trudeau administration's positive changes in protecting the environment since 2015 have lacked implementation and enforcement (Olive 2019). A contemporary example of this lack of implementation is moving forward with the Trans Mountain pipeline (also called the Kinder Morgan pipeline) (Tasker 2019). The Trans Mountain pipeline will bring oil from tar sands in Alberta to the British Columbia coast, representing a large traversal of land that crosses through natural protected areas, Indigenous lands, and the Rocky Mountains. Removing oil from tar sands is controversial as it is considered a dirty form of energy; thus, supporting this endeavor while equally tending to policies aimed at mitigating climate change represents a precarious balancing act between environmentalism and resource exploitation. This balancing between supporting large-scale resource extraction at times through economic incentives and environmental protection is a contemporary and historical issue in Canada and currently represents the largest hindrance for the country to move forward in environmental policy currently (Olive 2019).

Risk communication also presents challenges in creating fish consumption advisories in Canada. Policy risk can be an ambiguous term, but here risk communication is defined as an interactive process of exchange of information and opinion among individuals, groups, and institutions (Veres 1995). Risk communication is a difficult endeavor because the risk communicator must understand the scientific and technical information behind the risk being communicated, as well understand that the public has their own perceived risk and that they may disregard technical information or fail to understand it if perceived risk and appropriate language are not addressed (Veres 1995). For fish consumption advisories, technical information is not easily understood by the public and releasing an advisory without any mention of why consuming a contaminant is harmful to human health does not aid in public understanding of the situation (Veres 1995). This scientific information is still important but needs to be delivered in a way that the general public can grasp and that addresses the types of questions the public might have (Veres 1995). For example, a common question might be "why do I not get sick when I eat fish if the fish is contaminated?". Answering this question involves presenting scientific information on contaminants in fish tissue and their impact on human health and involves explaining that toxic doses of contaminants from consuming fishes are rare because health risks are based on cumulative exposure to contaminants; the concept of cumulative effects requires further explanation. Effective risk communication is especially important in conversing with vulnerable groups that are often the target demographics for fish consumption advisories. Additional barriers, including language, should be considered and risk communicators should be aware of additional barriers when devising communications about fish consumption advisories (Silver et al. 2007). Until risk communication efforts improve, fish consumption advisories cannot be expected to change fish consumption behaviors across Canada.

A final challenge to improved fish consumption advisories in Canada is a general lack of understanding on the presence and concentrations of contaminants in fishes and related fish consumption issues across many provinces and territories and at the federal level. For example, the Dehcho First Nation in the Northwest Territories is proposing fishing out the large fishes from contaminated lakes. As larger fish contain high levels of mercury because of bioaccumulation over many years, culling larger fish removes bioaccumulated mercury and can allow a fishery to develop based on a population of faster growing, younger fish $(C B C$ News 2015). This is considered a faster-developing fishery because fish will be caught at a younger age, 
thereby requiring less time between birth and catch. However, this does not eliminate mercury from the water and mercury can continue to accumulate even in younger fish, as well fishing out larger fish may collapse the fishery. Another example concerns point-source oriented testing regime in provinces like Nova Scotia that ignores the fact that non-point source pollution can just as easily result in high levels of contaminants in fish tissue because of bioaccumulation ("Guidance for Assessing Chemical Contaminant Data for Use in Fish Advisories" 1995). This testing regime was recently critiqued with only eighteen of sixty-four historical gold mine sites in Nova Scotia examined for mercury and arsenic contamination typical of such sites (Willick 2020). One study evaluating all previous mercury and arsenic contaminant monitoring surrounding historical gold mines in Nova Scotia stated, "If people are fishing near the sites... then [the contamination] could definitely be a concern" (Willick 2020). Clearly, fish contamination is misunderstood and underrepresented at both provincial and federal levels in Canada.

iv. What can Canada and the US learn from each other?

The US and Canada share marine and freshwater resources along their national border. This means policy solutions do not need to be independently derived in the two nations. Adapting current policy elements from federal, state, and provincial or territorial governments or even policies at the local level is possible and should be encouraged. Canada can most notably gain insights from the EPA and the Clean Water Act in the US. Although adapting the Clean Water Act would require rather extensive revisions to fit the Canadian federalist model, using it as a template to create mandatory fish contaminant monitoring across Canada would be a great opportunity to improve public health and environmental justice protections. Examples of adaptations of EPA guidelines to justify environmental decisions were done by LeBlanc and Halfyard (2010) for portion digestion in reviewing mercury and arsenic concentrations in fish tissue associated with historical gold mine tailings. The Clean Water Act provides a framework upon which other Canadian policies surrounding water use (e.g. Navigable Waters Act) could be built.
US state agencies that conduct extensive fish tissue monitoring programs can be a foundation for building similar programs in Canada. The Ontario fish tissue monitoring program is the most extensive in Canada, but it is much less extensive in comparison to the program in Alabama. In addition to the extensive list of contaminants for which Alabama monitors, the state monitors forty-to-fifty sites per year and collects 480-500 fishes for sampling from both predator and bottom-feeder populations ("Alabama Department of Environmental Management Fish Tissue Monitoring Program" 2007). Fish contaminant levels are monitored in the fall because many contaminants are stored in lipids and fatty tissues and are highest at this time of year ("Alabama Department of Environmental Management Fish Tissue Monitoring Program" 2007). Canada can adapt more extensive provincial programs from the most protective US state programs and/or adapt fish contaminant monitoring guidelines federally through legislation like the Clean Water Act. However, because the Clean Water Act results in such inconsistencies across US state monitoring programs, it seems the better option may be to take inspiration from strong state monitoring programs in setting federal and/or provincial requirements for fish contaminant monitoring. Strong US state programs are those that monitor the largest number of fish species from the largest number of lakes for the largest number of contaminants. Finally, Canada could adapt recommended guidelines for fish consumption advisory programs based on EPA guidelines. While guidelines and recommendations are not followed as rigorously as requirements, many US states benefit from having a series of recommendations when creating fish consumption advisory programs. Alterations of guidelines and recommendations to fit within state, provincial or territorial governance structures is likely necessary.

While the US is arguably ahead of Canada in designing and implementing fish consumption advisory programs, Canada provides important elements that the US could consider. For example, discussion surrounding risk communication appears much more extensive in Canada. Veres (1995) exclusively studied risk communication tactics in Nova Scotia surrounding site-specific PCB pollution 
to determine the best risk communication strategy for target demographics. Having appropriate research on risk communication in fish consumption advisories and recommendations for implementation is a step ahead of the US in such efforts. Improving risk communication increases awareness in target demographics and may be the most important first step to improving fish consumption advisories. Canada provides numerous tools to communicate with and respect Indigenous communities in environmental conversations and decision-making, including as it applies to fish consumption advisory programs. This stems most recently from implementing recommendations from the Truth and Reconciliation Commission concerning the history of Indigenous persecution in Canada. While this commission did not deal directly with involving Indigenous groups in environmental conversations, it does emphasize the need to respect Indigenous peoples and restore justice in such communities. These goals are not always accomplished (see access to safe drinking water in Indigenous communities, "Singh commits to lift all drinking water advisories in Indigenous communities by 2021" 2019), but currently more effort appears to be placed on addressing Indigenous concerns around environmental justice in Canada than in the US.

\section{Conclusion}

A review of fish consumption advisory programs in the US and Canada revealed that neither public health nor environmental justice are widely protected from contaminated recreationally caught fish consumption. Throughout the US all 50 states have fish consumption advisory programs because federal legislation through the Clean Water Act requires states to do so. In contrast, Canada has no federal-level legislation, though all provinces except Nunavut, have fish consumption advisory programs. However, there are very few fish consumption advisory programs at this time in the US or Canada that comprehensively monitor for environmental pollutants known to bioaccumulate in the food chain. Thus, to protect public health and promote environmental justice, increased fish tissue monitoring is needed in addition to improvements in health risk communication that reaches people consuming large amounts of fish. Policy changes that increase funding for fish consumption advisories will provide a safer food supply for some of the most vulnerable communities and help to reduce overall health disparities.

Appendices A: Table of fish consumption advisory programs across the 50 US states.

\begin{tabular}{|l|l|l|l|}
\hline State & Responsible Agency & Program Website & $\begin{array}{l}\text { Contaminants Monitored } \\
\text { in Fish }\end{array}$ \\
\hline Alabama & $\begin{array}{l}\text { Alabama Department of } \\
\text { Public Health, Alabama } \\
\text { Department of } \\
\text { Environmental } \\
\text { Management, Alabama } \\
\text { Department of } \\
\text { Conservation and } \\
\text { Natural Resources, } \\
\text { Tennessee Valley } \\
\text { Authority }\end{array}$ & $\begin{array}{l}\text { https://www.alabamapubli } \\
\text { chealth.gov/tox/fish-adviso } \\
\text { ries.html (accessed Mar } \\
\text { 2019) }\end{array}$ & $\begin{array}{l}\text { Arsenic, cadmium, lead, } \\
\text { mercury, selenium, } \\
\text { chlordane, chlorpyrifos, } \\
\end{array}$ \\
& & & $\begin{array}{l}\text { 4,4-DDD, 4,4-DDE, 4,4-DDT, } \\
\text { 2,4-DDD, 2,4-DDE, 2,4-DDT, } \\
\text { dieldrin, endosulfan I, } \\
\text { endosulfan II, endrin, } \\
\text { heptachlor, heptachlor } \\
\text { epoxide, hexachlorobenzene, } \\
\text { lindane, mirex, toxaphene, } \\
\text { PCBs, dioxin, relative weight, } \\
\text { additional contaminants as } \\
\text { necessary on Tier II basis } \\
\text { ("Alabama Department of } \\
\text { Environmental Management } \\
\end{array}$ \\
& & & $\begin{array}{l}\text { Fish Tissue Monitoring } \\
\text { Program" 2007) }\end{array}$ \\
\hline
\end{tabular}




\begin{tabular}{|c|c|c|c|}
\hline Alaska & $\begin{array}{l}\text { Alaska Department of } \\
\text { Health and Social } \\
\text { Services }\end{array}$ & $\begin{array}{l}\text { http://dhss.alaska.gov/dph } \\
\text { /Epi/eph/Pages/fish/defau } \\
\text { lt.aspx (accessed Mar 2019) }\end{array}$ & $\begin{array}{l}\text { Lead, mercury, POPs ("Fish } \\
\text { Facts and Consumption } \\
\text { Guidelines" n.d.) }\end{array}$ \\
\hline Arizona & $\begin{array}{l}\text { Arizona Department of } \\
\text { Environmental Quality }\end{array}$ & $\begin{array}{l}\text { https://azdeq.gov/fca } \\
\text { (accessed Mar 23, 2020) }\end{array}$ & $\begin{array}{l}\text { Mercury* ("Arizona Game } \\
\text { and Fish Department } \\
\text { 2015-2016 Annual Report" } \\
\text { n.d.) }\end{array}$ \\
\hline Arkansas & $\begin{array}{l}\text { Arkansas Department of } \\
\text { Public Health }\end{array}$ & $\begin{array}{l}\text { https://www.healthy.arkan } \\
\text { sas.gov/programs-services } \\
\text { /topics/fish-advisories } \\
\text { (accessed Mar 23, 2020) }\end{array}$ & $\begin{array}{l}\text { PCBs, dioxins, mercury } \\
\text { ("Fish Advisories" n.d.) }\end{array}$ \\
\hline California & $\begin{array}{l}\text { Office of Environmental } \\
\text { Health Hazard } \\
\text { Assessment }\end{array}$ & $\begin{array}{l}\text { https://oehha.ca.gov/fish } \\
\text { (accessed Mar 2019) }\end{array}$ & $\begin{array}{l}\text { Mercury, PCBs, DDT, dieldrin, } \\
\text { PBDEs, chlordane, selenium, } \\
\text { toxaphene ("Fish" n.d.) }\end{array}$ \\
\hline Colorado & $\begin{array}{l}\text { Colorado Department of } \\
\text { Public Health and } \\
\text { Environment }\end{array}$ & $\begin{array}{l}\text { https://www.colorado.gov/ } \\
\text { pacific/cdphe/wq-fish-cons } \\
\text { umption (accessed Mar } \\
\text { 2019) }\end{array}$ & $\begin{array}{l}\text { Mercury, selenium, arsenic } \\
\text { ("Fish Consumption } \\
\text { Program Summary" n.d.) }\end{array}$ \\
\hline Connecticut & $\begin{array}{l}\text { Connecticut State } \\
\text { Department of Public } \\
\text { Health. }\end{array}$ & $\begin{array}{l}\text { https://portal.ct.gov/DPH/ } \\
\text { Environmental-Health/Envi } \\
\text { ronmental-and-Occupation } \\
\text { al-Health-Assessment/CT-F } \\
\text { ish-Consumption-Advisory- } \\
\text { and-the-Safe-Eating-of-Fish } \\
\text {-Caught-in-Connecticut } \\
\text { (accessed Mar 23, 2020) }\end{array}$ & $\begin{array}{l}\text { Mercury, PCBs ("CT Fish } \\
\text { Consumption Advisory and } \\
\text { the Safe Eating of Fish } \\
\text { Caught in Connecticut" n.d.) }\end{array}$ \\
\hline Delaware & $\begin{array}{l}\text { State of Delaware } \\
\text { Division of Fish and } \\
\text { Wildlife, Department of } \\
\text { Natural Resources and } \\
\text { Environmental Control, } \\
\text { Department of Health } \\
\text { and Social Services } \\
\text { Division of Public Health }\end{array}$ & $\begin{array}{l}\text { http://www.dnrec.delawar } \\
\text { e.gov/fw/Fisheries/Pages/ } \\
\text { Advisories.aspx (accessed } \\
\text { Mar 2019) }\end{array}$ & $\begin{array}{l}\text { PCBs, mercury, } \\
\text { dioxins/furans, DDT } \\
\text { ("Delaware } 2018 \text { Fish } \\
\text { Consumption Advisory Data" } \\
\text { n.d.) }\end{array}$ \\
\hline Florida & $\begin{array}{l}\text { Florida Department of } \\
\text { Health, Florida } \\
\text { Department of } \\
\text { Environmental } \\
\text { Protection and } \\
\text { Agricultural and } \\
\text { Consumer Services, } \\
\text { Florida Fish and Wildlife } \\
\text { Conservation } \\
\text { Commission } \\
\end{array}$ & $\begin{array}{l}\text { http://www.floridahealth.g } \\
\text { ov/programs-and-services/ } \\
\text { prevention/healthy-weight } \\
\text { /nutrition/seafood-consum } \\
\text { ption/fish-advisories-page. } \\
\text { html (accessed Mar 2019) }\end{array}$ & $\begin{array}{l}\text { Mercury, dioxins, pesticides, } \\
\text { PCBs, saxitoxin, arsenic, lead } \\
\text { ("Your Guide To Eating Fish } \\
\text { Caught In Florida" 2018) }\end{array}$ \\
\hline Georgia & $\begin{array}{l}\text { Georgia Department of } \\
\text { Natural Resources }\end{array}$ & $\begin{array}{l}\text { https://epd.georgia.gov/fis } \\
\text { h-consumption-guidelines } \\
\text { (accessed Mar 23, 2020) }\end{array}$ & $\begin{array}{l}\text { Chlordane, PCBs, mercury, } \\
\text { DDT/DDD/DDE, toxaphene, } \\
\text { dieldrin ("Guidelines For }\end{array}$ \\
\hline
\end{tabular}




\begin{tabular}{|c|c|c|c|}
\hline & & & $\begin{array}{l}\text { Eating Fish From Georgia } \\
\text { Waters" 2018) }\end{array}$ \\
\hline Hawaii $^{* *}$ & $\begin{array}{l}\text { Hawaii State } \\
\text { Department of Health }\end{array}$ & $\begin{array}{l}\text { http://www.hawaiihealthm } \\
\text { atters.org/promisepractice } \\
\text { /index/view?pid=447 } \\
\text { (accessed Mar 23, 2020) }\end{array}$ & $\begin{array}{l}\text { PCBs ("Fish Advisory } \\
\text { Program" n.d.) }\end{array}$ \\
\hline Idaho & $\begin{array}{l}\text { Idaho Department of } \\
\text { Health and Welfare, } \\
\text { Idaho Department of } \\
\text { Environmental Quality, } \\
\text { Idaho Department of } \\
\text { Fish and Game, Idaho } \\
\text { Department of } \\
\text { Agriculture } \\
\end{array}$ & $\begin{array}{l}\text { https://healthandwelfare.i } \\
\text { daho.gov/Health/Environm } \\
\text { entalHealth/FishAdvisories } \\
\text { /tabid/180/Default.aspx } \\
\text { (accessed Mar 2019) }\end{array}$ & $\begin{array}{l}\text { Selenium, mercury, PCBs, } \\
\text { PBDEs, selected metals, } \\
\text { pesticides ("Idaho Fish } \\
\text { Consumption Advisory } \\
\text { Project Protocol" n.d.) }\end{array}$ \\
\hline Illinois & $\begin{array}{l}\text { Illinois Department of } \\
\text { Public Health, Illinois } \\
\text { Department of } \\
\text { Agriculture, Illinois } \\
\text { Department of Natural } \\
\text { Resources, Illinois } \\
\text { Emergency Management } \\
\text { Agency, Illinois } \\
\text { Environmental } \\
\text { Protection Agency } \\
\end{array}$ & $\begin{array}{l}\text { http://www.dph.illinois.go } \\
\text { v/topics-services/environ } \\
\text { mental-health-protection/t } \\
\text { oxicology/fish-advisories } \\
\text { (accessed Mar 2019) }\end{array}$ & $\begin{array}{l}\text { PCBs, chlordane, mercury, } \\
\text { dioxins, } 11 \text { additional } \\
\text { banned pesticides ("Fish } \\
\text { Advisories in Illinois" n.d.) }\end{array}$ \\
\hline Indiana & $\begin{array}{l}\text { Indiana State } \\
\text { Department of Health, } \\
\text { Indiana Department of } \\
\text { Environmental } \\
\text { Management, Indiana } \\
\text { Department of Natural } \\
\text { Resources }\end{array}$ & $\begin{array}{l}\text { https://secure.in.gov/isdh/ } \\
\text { 23650.htm (accessed } \\
\text { March 2019) }\end{array}$ & $\begin{array}{l}\text { Mercury, PCBs, cadmium, } \\
\text { lead, selenium, PFAS, legacy } \\
\text { organochlorine pesticides } \\
\text { ("Contaminants in Fish" n.d.) }\end{array}$ \\
\hline Iowa & $\begin{array}{l}\text { Iowa Department of } \\
\text { Natural Resources }\end{array}$ & $\begin{array}{l}\text { https://www.iowadnr.gov/ } \\
\text { Environmental-Protection/ } \\
\text { Water-Quality/Water-Moni } \\
\text { toring/Fish-Tissue } \\
\text { (accessed Mar 23, 2020) }\end{array}$ & $\begin{array}{l}\text { Mercury, PCBs, chlordane, } \\
\text { DDE, dieldrin ("Ambient Fish } \\
\text { and Turtle Tissue } \\
\text { Monitoring" n.d.) }\end{array}$ \\
\hline Kansas & $\begin{array}{l}\text { Kansas Department of } \\
\text { Health and Environment }\end{array}$ & $\begin{array}{l}\text { http://www.kdheks.gov/be } \\
\text { fs/fish_tissue_monitoring.ht } \\
\text { m (accessed Mar 2019) }\end{array}$ & $\begin{array}{l}\text { Cadmium, lead, mercury, } \\
\text { chlordane, dioxins/furans, } \\
\text { DDT, PCBs, heptachlor } \\
\text { epoxide, other toxic metals } \\
\text { and legacy organic } \\
\text { pollutants ("Fish Tissue } \\
\text { Contaminant Monitoring } \\
\text { Program" n.d.) }\end{array}$ \\
\hline Kentucky & $\begin{array}{l}\text { Kentucky Department of } \\
\text { Environmental } \\
\text { Protection, Kentucky } \\
\text { Department of Health }\end{array}$ & $\begin{array}{l}\text { https://fw.ky.gov/Fish/Pag } \\
\text { es/Fish-Consumption-Advis } \\
\text { ories.aspx (accessed Mar } \\
\text { 23, 2020) }\end{array}$ & $\begin{array}{l}\text { PCBs, mercury ("Fish } \\
\text { Consumption Advisories" } \\
\text { n.d.) }\end{array}$ \\
\hline
\end{tabular}




\begin{tabular}{|c|c|c|c|}
\hline & $\begin{array}{l}\text { Services, Kentucky } \\
\text { Department of Fish and } \\
\text { Wildlife Resources } \\
\end{array}$ & & \\
\hline Louisiana & $\begin{array}{l}\text { Louisiana Wildlife and } \\
\text { Fisheries, Louisiana } \\
\text { Department of } \\
\text { Environmental Quality, } \\
\text { Louisiana Department of } \\
\text { Health }\end{array}$ & $\begin{array}{l}\text { http://www.wlf.louisiana.g } \\
\text { ov/fishing/fish-consumptio } \\
\text { n-advisory (accessed Mar } \\
\text { 2019) }\end{array}$ & $\begin{array}{l}\text { Mercury, dioxins/furans, } \\
\text { DDT, toxaphene, PAHs, } \\
\text { benzo(a)pyrene, PCBs, } \\
\text { hexachlorobenzene, } \\
\text { hexachlorobutadiene, } \\
\text { arsenic, lead, other organic } \\
\text { chemicals ("Fishing } \\
\text { Consumption and Swimming } \\
\text { Advisories" n.d.) }\end{array}$ \\
\hline Maine & $\begin{array}{l}\text { Maine Department of } \\
\text { Inland Fisheries and } \\
\text { Wildlife, Maine Center } \\
\text { for Disease Control and } \\
\text { Prevention }\end{array}$ & $\begin{array}{l}\text { https://www.maine.gov/if } \\
\text { w/fishing-boating/fishing/l } \\
\text { aws-rules/consumption-ad } \\
\text { visory.html (accessed Mar } \\
\text { 2019) }\end{array}$ & $\begin{array}{l}\text { Mercury, PCBs, dioxins, DDT } \\
\text { ("Fish Consumption } \\
\text { Advisory" n.d.) }\end{array}$ \\
\hline Maryland & $\begin{array}{l}\text { Maryland Department of } \\
\text { the Environment }\end{array}$ & $\begin{array}{l}\text { https://mde.maryland.gov/ } \\
\text { programs/Marylander/fish } \\
\text { andshellfish/Pages/fishcon } \\
\text { sumptionadvisory.aspx } \\
\text { (accessed Mar 2019) }\end{array}$ & $\begin{array}{l}\text { PCBs, chlorinated pesticides } \\
\text { (including DDT and } \\
\text { dieldrin), mercury ("MDE } \\
\text { Fish Consumption Advisory" } \\
\text { n.d.) }\end{array}$ \\
\hline Massachusetts & $\begin{array}{l}\text { Massachusetts Bureau } \\
\text { of Environmental Health }\end{array}$ & $\begin{array}{l}\text { https://www.mass.gov/inf } \\
\text { o-details/eating-fish-safely- } \\
\text { in-massachusetts (accessed } \\
\text { Mar 23, 2020) }\end{array}$ & $\begin{array}{l}\text { Mercury, PCBs ("Eating Fish } \\
\text { Safely in Massachusetts" } \\
\text { n.d.) }\end{array}$ \\
\hline Michigan & $\begin{array}{l}\text { Michigan Department of } \\
\text { Health and Human } \\
\text { Services, Michigan } \\
\text { Department of Natural } \\
\text { Resources }\end{array}$ & $\begin{array}{l}\text { https://www.michigan.gov } \\
\text { /mdhhs/0,5885,7-339-715 } \\
\text { 48_54783_54784_54785_5 } \\
\text { 8671-296074--,00.html } \\
\text { (accessed Mar 23, 2020) }\end{array}$ & $\begin{array}{l}\text { Mercury, PFAS, PFOS, PCBs } \\
\text { ("PFAS in Fish" n.d.) }\end{array}$ \\
\hline Minnesota & $\begin{array}{l}\text { Minnesota Department } \\
\text { of Natural Resources, } \\
\text { Minnesota Department } \\
\text { of Health, Minnesota } \\
\text { Department of } \\
\text { Agriculture, Minnesota } \\
\text { Pollution Control } \\
\text { Agency }\end{array}$ & $\begin{array}{l}\text { https://www.health.state.m } \\
\text { n.us/communities/environ } \\
\text { ment/fish/ (accessed Mar } \\
\text { 2019) }\end{array}$ & $\begin{array}{l}\text { Mercury, PCBs, dioxins, } \\
\text { PAHs, pesticides, other } \\
\text { contaminants in special } \\
\text { studies ("Minnesota's Fish } \\
\text { Contaminant Monitoring } \\
\text { Program" 2008) }\end{array}$ \\
\hline Mississippi & $\begin{array}{l}\text { Mississippi Department } \\
\text { of Wildlife, Fisheries, } \\
\text { and Parks, Mississippi } \\
\text { Department of } \\
\text { Environmental Quality }\end{array}$ & $\begin{array}{l}\text { https://www.mdwfp.com/f } \\
\text { ishing-boating/environmen } \\
\text { tal-program/ (accessed Mar } \\
23,2020 \text { ) }\end{array}$ & $\begin{array}{l}\text { Pesticides, mercury, PCBs, } \\
\text { DDT, toxaphene ("State of } \\
\text { Mississippi Water Quality } \\
\text { Assessment } 2018 \text { Section } \\
\text { 305(b) Report" 2018) }\end{array}$ \\
\hline Missouri & $\begin{array}{l}\text { Missouri Department of } \\
\text { Health and Senior } \\
\text { Services, Missouri }\end{array}$ & $\begin{array}{l}\text { https://health.mo.gov/livin } \\
\text { g/environment/fishadvisor } \\
\text { y/ (accessed Mar 2019) }\end{array}$ & $\begin{array}{l}\text { Chlordane, mercury, PCBs, } \\
\text { lead ("2020 Missouri Fish } \\
\text { Advisory: A Guide to Eating } \\
\text { Missouri Fish" n.d.) }\end{array}$ \\
\hline
\end{tabular}




\begin{tabular}{|c|c|c|c|}
\hline & $\begin{array}{l}\text { Department of } \\
\text { Conservation }\end{array}$ & & \\
\hline Montana & $\begin{array}{l}\text { Montana Fish, Wildlife, } \\
\text { and Parks, Montana } \\
\text { Department of } \\
\text { Environmental Quality, } \\
\text { Montana Department of } \\
\text { Health and Human } \\
\text { Services }\end{array}$ & $\begin{array}{l}\text { http://fwp.mt.gov/fish/ang } \\
\text { lingData/ (accessed Mar } \\
\text { 2019) }\end{array}$ & $\begin{array}{l}\text { Mercury, PCBs, arsenic, } \\
\text { cadmium, selenium, } \\
\text { dioxins/furans, other metals, } \\
\text { pesticides, and organic } \\
\text { compounds ("Montana Sport } \\
\text { Fish Consumption } \\
\text { Guidelines" n.d.) } \\
\end{array}$ \\
\hline Nebraska & $\begin{array}{l}\text { Nebraska Department of } \\
\text { Environmental Quality, } \\
\text { Nebraska Department of } \\
\text { Health and Human } \\
\text { Services, Nebraska } \\
\text { Game and Parks } \\
\text { Commission, Nebraska } \\
\text { Department of } \\
\text { Agriculture }\end{array}$ & $\begin{array}{l}\text { http://deq.ne.gov/NDEQPr } \\
\text { og.nsf/OnWeb/FTMP } \\
\text { (accessed Mar 2019) }\end{array}$ & $\begin{array}{l}\text { PCBs, mercury, dieldrin, } \\
\text { selenium, heavy metals, } \\
\text { pesticides, other organic } \\
\text { compounds ("Fish Tissue } \\
\text { Monitoring Program" n.d.) }\end{array}$ \\
\hline Nevada & $\begin{array}{l}\text { Nevada Department of } \\
\text { Wildlife, Nevada } \\
\text { Division of } \\
\text { Environmental } \\
\text { Protection, Nevada } \\
\text { Division of Public and } \\
\text { Behavioral Health } \\
\end{array}$ & $\begin{array}{l}\text { http://www.ndow.org/Fish } \\
\text { /Fish_Safety/ (accessed } \\
\text { Mar 2019) }\end{array}$ & $\begin{array}{l}\text { Mercury ("Fish Consumption } \\
\text { Safety" n.d.) }\end{array}$ \\
\hline New Hampshire & $\begin{array}{l}\text { New Hampshire } \\
\text { Department of } \\
\text { Environmental Services }\end{array}$ & $\begin{array}{l}\text { https://www.wildlife.state. } \\
\text { nh.us/fishing/consume-fre } \\
\text { sh.html (accessed Mar } \\
\text { 2019) }\end{array}$ & $\begin{array}{l}\text { Mercury, dioxins, PCBs (M. } \\
\text { Wood and Edwardson 2020) }\end{array}$ \\
\hline New Jersey & $\begin{array}{l}\text { State of New Jersey } \\
\text { Department of } \\
\text { Environmental } \\
\text { Protection, New Jersey } \\
\text { Department of Health } \\
\end{array}$ & $\begin{array}{l}\text { https://www.nj.gov/dep/d } \\
\text { sr/njmainfish.htm } \\
\text { (accessed Mar 2019) }\end{array}$ & $\begin{array}{l}\text { PCBs, dioxins, mercury } \\
\text { ("2018 Fish Smart, Eat } \\
\text { Smart" n.d.) }\end{array}$ \\
\hline New Mexico & $\begin{array}{l}\text { New Mexico } \\
\text { Environment } \\
\text { Department, New } \\
\text { Mexico Department of } \\
\text { Game and Fish, New } \\
\text { Mexico Department of } \\
\text { Health } \\
\end{array}$ & $\begin{array}{l}\text { https://nmtrackingtest.hea } \\
\text { lth.state.nm.us/environmen } \\
\text { t/FishConsumption.html } \\
\text { (accessed Mar 23, 2020) }\end{array}$ & $\begin{array}{l}\text { Mercury, selenium, DDT, } \\
\text { PCBs, PBDEs, dioxins/furans, } \\
\text { other organochlorine } \\
\text { pesticides ("New Mexico } \\
\text { Fish Consumption } \\
\text { Advisories" 2012) }\end{array}$ \\
\hline New York & $\begin{array}{l}\text { New York State } \\
\text { Department of } \\
\text { Environmental } \\
\text { Conservation, New York } \\
\text { State Department of } \\
\text { Health }\end{array}$ & $\begin{array}{l}\text { https://www.health.ny.gov } \\
\text { /environmental/outdoors/f } \\
\text { ish/health_advisories/ } \\
\text { (accessed Mar 23, 2020) }\end{array}$ & $\begin{array}{l}\text { PCBs, PFAS, mercury, } \\
\text { chlordane, DDT, dieldrin, } \\
\text { mirex, dioxins /furans, } \\
\text { cadmium, lead ("About } \\
\text { Chemicals and Bacteria in } \\
\text { Fish and Additional } \\
\text { Information" n.d.) }\end{array}$ \\
\hline
\end{tabular}




\begin{tabular}{|c|c|c|c|}
\hline North Carolina & $\begin{array}{l}\text { North Carolina } \\
\text { Department of } \\
\text { Environmental Quality, } \\
\text { North Carolina } \\
\text { Department of Health } \\
\text { and Human Services } \\
\end{array}$ & $\begin{array}{l}\text { https://epi.publichealth.nc. } \\
\text { gov/oee/programs/fish.ht } \\
\text { ml (accessed Mar 23, 2020) }\end{array}$ & $\begin{array}{l}\text { Dioxins, mercury, PCBs, } \\
\text { arsenic, hexavalent } \\
\text { chromium ("Fish } \\
\text { Consumption Advisories" } \\
\text { n.d.) }\end{array}$ \\
\hline North Dakota & $\begin{array}{l}\text { North Dakota } \\
\text { Department of Health, } \\
\text { North Dakota Game and } \\
\text { Fish Department } \\
\end{array}$ & $\begin{array}{l}\text { https://deq.nd.gov/topicsA } \\
\text { toZ.aspx (accessed Mar } \\
\text { 2019) }\end{array}$ & $\begin{array}{l}\text { Mercury ("Fish Consumption } \\
\text { Advisory for Waters of North } \\
\text { Dakota" 2001) }\end{array}$ \\
\hline Ohio & $\begin{array}{l}\text { Ohio Department of } \\
\text { Health, Ohio } \\
\text { Environmental } \\
\text { Protection Agency, Ohio } \\
\text { Department of Natural } \\
\text { Resources }\end{array}$ & $\begin{array}{l}\text { https://www.epa.ohio.gov/ } \\
\text { dsw/fishadvisory/index\#1 } \\
\text { 45215084-ohios-sport-fish- } \\
\text { tissue-monitoring } \\
\text { (accessed Mar 23, } 2020\end{array}$ & $\begin{array}{l}\text { Aldrin, arsenic, cadmium, } \\
\text { chlordane, nonachlor, } \\
\text { 4-4'-DDT, 4-4'-DDE, } \\
\text { 4-4'-DDD, dieldrin, } \\
\text { endosulfan, endrin, } \\
\text { heptachlor, heptachlor } \\
\text { epoxide, hexachlorobenzene, } \\
\text { lead, methoxychlor, mirex, } \\
\text { mercury, PCBs ("State of } \\
\text { Ohio Cooperative Fish Tissue } \\
\text { Monitoring Program Fish } \\
\text { Tissue Environmental } \\
\text { Assessment Program" 2005) }\end{array}$ \\
\hline Oklahoma & $\begin{array}{l}\text { Oklahoma Department } \\
\text { of Environmental } \\
\text { Quality } \\
\end{array}$ & $\begin{array}{l}\text { http://www.deq.state.ok.us } \\
\text { /CSDnew/fish/index.htm } \\
\text { (accessed Mar 2019) }\end{array}$ & $\begin{array}{l}\text { Mercury, pesticides, lead } \\
\text { ("Environmental and Public } \\
\text { Health Information" n.d.) }\end{array}$ \\
\hline Oregon & Oregon Health Authority & $\begin{array}{l}\text { http://www.eregulations.c } \\
\text { om/oregon/fishing/advisor } \\
\text { ies-consumption-guidelines } \\
\text { / (accessed Mar 23, 2020) }\end{array}$ & $\begin{array}{l}\text { Arsenic, cadmium, mercury, } \\
\text { selenium, tributyltin, aldrin, } \\
\text { chlordane, DDT, dicofol, } \\
\text { dieldrin, endosulfan, endrin, } \\
\text { heptachlor epoxide, } \\
\text { hexachlorobenzene, lindane, } \\
\text { methoxychlor, mirex, } \\
\text { toxaphene, chlorpyrifos, } \\
\text { diazinon, disulfoton, ethion, } \\
\text { terbufos, oxyfluorfen, PCBs, } \\
\text { dioxins/furans, brominated } \\
\text { flame retardants, PFCs ("Fish } \\
\text { Consumption Advisory } \\
\text { Standard Operating } \\
\text { Guidance (SOG) Oregon } \\
\text { Health Authority (OHA) Fish } \\
\text { Advisory Program" 2018) }\end{array}$ \\
\hline Pennsylvania & $\begin{array}{l}\text { Pennsylvania } \\
\text { Department of } \\
\text { Environmental } \\
\text { Protection, Pennsylvania } \\
\text { Department of Health, }\end{array}$ & $\begin{array}{l}\text { https://www.dep.pa.gov/B } \\
\text { usiness/Water/CleanWater } \\
\text { /WaterQuality/FishConsum } \\
\text { ptionAdvisory/Pages/defau } \\
\text { lt.aspx (accessed Mar 2019) }\end{array}$ & $\begin{array}{l}\text { PCBs, mercury, chlordane, } \\
\text { aldrin, dieldrin, chlordecone, } \\
\text { DDT, DDE, TDE, heptachlor, } \\
\text { heptachlor epoxide, mirex } \\
\text { ("Fish Consumption" n.d.) }\end{array}$ \\
\hline
\end{tabular}




\begin{tabular}{|c|c|c|c|}
\hline & $\begin{array}{l}\text { Pennsylvania Fish and } \\
\text { Boat Commission }\end{array}$ & & \\
\hline Rhode Island & $\begin{array}{l}\text { Rhode Island } \\
\text { Department of } \\
\text { Environmental } \\
\text { Management }\end{array}$ & $\begin{array}{l}\text { http://www.rimonitoring.o } \\
\text { rg/toxic-mercury-in-fish/ } \\
\text { (accessed Mar 2019) }\end{array}$ & $\begin{array}{l}\text { Mercury* ("Fish Is Good, } \\
\text { Mercury Is Bad" n.d.) }\end{array}$ \\
\hline South Carolina & $\begin{array}{l}\text { South Carolina } \\
\text { Department of Health } \\
\text { and Environmental } \\
\text { Control }\end{array}$ & $\begin{array}{l}\text { https://www.scdhec.gov/fo } \\
\text { od-safety/food-monitoring- } \\
\text { advisories/fish-consumptio } \\
\text { n-advisories (accessed Mar } \\
\text { 2019) }\end{array}$ & $\begin{array}{l}\text { Mercury, PCBs, radioisotopes } \\
\text { ("What Are Fish } \\
\text { Consumption Advisories?" } \\
\text { n.d.) }\end{array}$ \\
\hline South Dakota & $\begin{array}{l}\text { South Dakota } \\
\text { Department of Game, } \\
\text { Fish, and Parks, South } \\
\text { Dakota Department of } \\
\text { Environment and } \\
\text { Natural Resources, } \\
\text { South Dakota } \\
\text { Department of Health }\end{array}$ & $\begin{array}{l}\text { https://doh.sd.gov/food/S } \\
\text { Dadvisories.aspx (accessed } \\
\text { Mar 2019) }\end{array}$ & $\begin{array}{l}\text { Cadmium, selenium, } \\
\text { pesticides, PCBs, mercury } \\
\text { ("South Dakota Fish } \\
\text { Consumption Advisories" } \\
\text { n.d.) }\end{array}$ \\
\hline Tennessee & $\begin{array}{l}\text { Tennessee Department } \\
\text { of Environment and } \\
\text { Conservation }\end{array}$ & $\begin{array}{l}\text { https://issuu.com/thebing } \\
\text { hamgroup/docs/twrafishin } \\
\text { g2018_interactive/36 } \\
\text { (accessed Mar 23, 2020) }\end{array}$ & $\begin{array}{l}\text { Mercury, PCBs, chlordane, } \\
\text { other pesticides, other } \\
\text { organics ("TN Fishing Guide } \\
\text { 2018-2019" 2018) }\end{array}$ \\
\hline $\operatorname{Texas}^{* * *}$ & $\begin{array}{l}\text { Texas Department of } \\
\text { State Health and } \\
\text { Services }\end{array}$ & $\begin{array}{l}\text { https://tpwd.texas.gov/reg } \\
\text { ulations/outdoor-annual/fi } \\
\text { shing/general-rules-regulat } \\
\text { ions/fish-consumption-ban } \\
\text { s-and-advisories (accessed } \\
\text { Mar 2019) }\end{array}$ & $\begin{array}{l}\text { PCBs, dioxins, mercury, } \\
\text { dieldrin, DDT, DDE, DDD, } \\
\text { chlordane, toxaphene, aldrin, } \\
\text { VOCs ("General Information } \\
\text { on the Risk of Eating Fish - } \\
\text { Seafood and Aquatic Life" } \\
\text { n.d.) }\end{array}$ \\
\hline Utah & $\begin{array}{l}\text { Utah Department of } \\
\text { Environmental Quality, } \\
\text { Utah Department of } \\
\text { Health }\end{array}$ & $\begin{array}{l}\text { https://deq.utah.gov/fish-a } \\
\text { dvisories/utah-fish-advisor } \\
\text { ies (accessed Mar 2019) }\end{array}$ & $\begin{array}{l}\text { Arsenic, mercury, selenium, } \\
\text { PCBs ("Utah Fish Advisories" } \\
\text { n.d.) }\end{array}$ \\
\hline Vermont & $\begin{array}{l}\text { Vermont Department of } \\
\text { Health, Vermont } \\
\text { Department of } \\
\text { Environmental } \\
\text { Conservation, Vermont } \\
\text { Department of Fish and } \\
\text { Wildlife }\end{array}$ & $\begin{array}{l}\text { https://dec.vermont.gov/w } \\
\text { aste-management/solid/pr } \\
\text { oduct-stewardship/mercur } \\
\text { y/fish (accessed Mar 2019) }\end{array}$ & $\begin{array}{l}\text { Mercury, PCBs ("Health } \\
\text { Alert" 2013) }\end{array}$ \\
\hline Virginia & $\begin{array}{l}\text { Virginia Department of } \\
\text { Environmental Quality, } \\
\text { Virginia Department of } \\
\text { Health }\end{array}$ & $\begin{array}{l}\text { https://www.dgif.virginia.g } \\
\text { ov/fishing/regulations/fish } \\
\text {-consumption-advisories/ } \\
\text { (accessed Mar 2019) }\end{array}$ & $\begin{array}{l}\text { Mercury, PCBs, pesticide, } \\
\text { organic chemicals } \\
\text { ("Frequently Asked } \\
\text { Questions about } \\
\text { Polychlorinated Biphenyls } \\
\text { (PCBs) and Mercury Fish }\end{array}$ \\
\hline
\end{tabular}




\begin{tabular}{|c|c|c|c|}
\hline & & & $\begin{array}{l}\text { Consumption Advisories in } \\
\text { Virginia Waters" n.d.) }\end{array}$ \\
\hline Washington & $\begin{array}{l}\text { Washington State } \\
\text { Department of Health, } \\
\text { Washington State } \\
\text { Department of Ecology, } \\
\text { Washington Department } \\
\text { of Fish and Wildlife }\end{array}$ & $\begin{array}{l}\text { https://www.doh.wa.gov/C } \\
\text { ommunityandEnvironment } \\
\text { /Food/Fish/Advisories } \\
\text { (accessed Mar 2019) }\end{array}$ & $\begin{array}{l}\text { Mercury, PCBs, PBDEs, } \\
\text { dioxins, chlorinated } \\
\text { pesticides, DDT, lead } \\
\text { ("Contaminants in Fish" n.d.) }\end{array}$ \\
\hline West Virginia & $\begin{array}{l}\text { West Virginia } \\
\text { Department of Health } \\
\text { and Human Resources, } \\
\text { West Virginia } \\
\text { Department of } \\
\text { Environmental } \\
\text { Protection, West } \\
\text { Virginia Division of } \\
\text { Natural Resources } \\
\end{array}$ & $\begin{array}{l}\text { https://www.wvdhhr.org/fi } \\
\text { sh/Current_Advisories.asp } \\
\text { (accessed Mar 2019) }\end{array}$ & $\begin{array}{l}\text { Mercury, PCBs, selenium, } \\
\text { dioxin ("Contaminants and } \\
\text { Health Risks" n.d.) }\end{array}$ \\
\hline Wisconsin & $\begin{array}{l}\text { Wisconsin Department } \\
\text { of Health and Services, } \\
\text { Wisconsin Department } \\
\text { of Natural Resources }\end{array}$ & $\begin{array}{l}\text { https://dnr.wi.gov/topic/fi } \\
\text { shing/consumption/ } \\
\text { (accessed Mar 2019) }\end{array}$ & $\begin{array}{l}\text { Mercury, PCBs, } \\
\text { dioxins/furans, PFOS, DDT, } \\
\text { chlordane, dieldrin, aldrin, } \\
\text { toxaphene, other } \\
\text { organochlorine pesticides } \\
\text { (Schrank n.d.) }\end{array}$ \\
\hline Wyoming & $\begin{array}{l}\text { Wyoming Department of } \\
\text { Health, Wyoming Game } \\
\text { and Fish Department }\end{array}$ & $\begin{array}{l}\text { https://wgfd.wyo.gov/Fishi } \\
\text { ng-and-Boating/Fish-Consu } \\
\text { mption-Advice/ (accessed } \\
\text { Mar 2019) }\end{array}$ & $\begin{array}{l}\text { Mercury ("Fish Consumption } \\
\text { Advice" n.d.) }\end{array}$ \\
\hline
\end{tabular}

*Department is beginning a PCB monitoring program, but scope is limited.

**State does not conduct its own monitoring. All monitoring is carried out by US EPA representatives.

***State has fish consumption advisories, but also fish consumption bans. Bans make possessing or eating fish from identified waterbody illegal.

Appendix B: Table of fish consumption advisory programs across the 13 Canadian provinces and territories.

\begin{tabular}{|l|l|l|l|}
\hline Province/Territory & Responsible Agency & Program Website & $\begin{array}{l}\text { Contaminants } \\
\text { Monitored in Fish }\end{array}$ \\
\hline British Columbia & $\begin{array}{l}\text { British Columbia Ministry } \\
\text { of Environment, Lands and } \\
\text { Parks; Department of } \\
\text { Fisheries and Oceans; } \\
\text { British Columbia Ministry } \\
\text { of Agriculture, Food, and } \\
\text { Fisheries; British Columbia } \\
\text { Ministry of Water, Land, } \\
\text { and Air Protection }\end{array}$ & $\begin{array}{l}\text { https://wwwhealthlinkbc. } \\
\text { ca/healthlinkbc-files/merc } \\
\text { ury-fish (accessed Mar 23, } \\
\text { 2020) }\end{array}$ & $\begin{array}{l}\text { dioxins/furans*, } \\
\text { mercury*, } \\
\text { organochlorine } \\
\text { pesticides*, PCBs*, } \\
\text { heavy metals* (M. E. } \\
\text { Wood 2001) }\end{array}$ \\
\hline
\end{tabular}




\begin{tabular}{|c|c|c|c|}
\hline Alberta & $\begin{array}{l}\text { Alberta Fish and Wildlife; } \\
\text { Alberta Health and } \\
\text { Wellness; Alberta } \\
\text { Environment }\end{array}$ & $\begin{array}{l}\text { https://mywildalberta.ca/f } \\
\text { ishing/advisories-correctio } \\
\text { ns-closures/fish-consumpt } \\
\text { ion-advisory.aspx } \\
\text { (accessed Oct 2019) }\end{array}$ & $\begin{array}{l}\text { dioxins/furans, } \\
\text { mercury ("Fish } \\
\text { Consumption Advisory" } \\
\text { n.d.) }\end{array}$ \\
\hline Saskatchewan & $\begin{array}{l}\text { Saskatchewan Environment } \\
\text { and Resources } \\
\text { Management; } \\
\text { Saskatchewan Ministry of } \\
\text { Environment; } \\
\text { Saskatchewan Ministry of } \\
\text { Health } \\
\end{array}$ & $\begin{array}{l}\text { https://www.saskatchewa } \\
\text { n.ca/residents/parks-cultu } \\
\text { re-heritage-and-sport/hun } \\
\text { ting-trapping-and-angling/ } \\
\text { angling/fish-populations- } \\
\text { management-and-research } \\
\text { (accessed Oct 2019) }\end{array}$ & $\begin{array}{l}\text { Mercury ("Mercury in } \\
\text { Saskatchewan Fish: } \\
\text { Guidelines for } \\
\text { Consumption Updated } \\
\text { to } 2015 \text { " n.d.) }\end{array}$ \\
\hline Manitoba & $\begin{array}{l}\text { Manitoba Department of } \\
\text { Conservation; Manitoba } \\
\text { Water Stewardship; } \\
\text { Manitoba Hydro; } \\
\text { Department of Fisheries } \\
\text { and Oceans }\end{array}$ & $\begin{array}{l}\text { https://www.gov.mb.ca/w } \\
\text { aterstewardship/fisheries/ } \\
\text { education/mercury_final_n } \\
\text { ov_2007.pdf (accessed Oct } \\
\text { 2019) }\end{array}$ & $\begin{array}{l}\text { Mercury ("Mercury in } \\
\text { Fish" n.d.) }\end{array}$ \\
\hline Ontario & $\begin{array}{l}\text { Ontario Ministry of the } \\
\text { Environment; Ontario } \\
\text { Ministry of Natural } \\
\text { Resources }\end{array}$ & $\begin{array}{l}\text { https://www.ontario.ca/p } \\
\text { age/eating-ontario-fish-20 } \\
\text { 17-18 (accessed Oct 2019) }\end{array}$ & $\begin{array}{l}\text { mercury, PCBs, mirex, } \\
\text { DDT, dioxin-like PCBs, } \\
\text { dioxins/furans, } \\
\text { toxaphene, PFAS, } \\
\text { selenium, arsenic, } \\
\text { PBDEs, PCNs, } \\
\text { chromium, photomirex, } \\
\text { lead, cadmium ("Map: } \\
\text { Guide to Eating Ontario } \\
\text { Fish" n.d.) }\end{array}$ \\
\hline Quebec & $\begin{array}{l}\text { Ministère de } \\
\text { l'Environnement du } \\
\text { Québec; Société de la faune } \\
\text { et des parcs du Québec; } \\
\text { Ministère de la Santé et des } \\
\text { Services Sociaux }\end{array}$ & $\begin{array}{l}\text { https://www.quebec.ca/en } \\
\text { /health/advice-and-preven } \\
\text { tion/healthy-lifestyle-habit } \\
\text { s/fish-consumption-and-h } \\
\text { ealth/recommendations/ } \\
\text { (accessed Oct } 2019\end{array}$ & $\begin{array}{l}\text { mercury, PCBs, dioxins, } \\
\text { furans, PBDEs, arsenic, } \\
\text { cadmium, lead, } \\
\text { selenium, other metals } \\
\text { and synthetic } \\
\text { molecules* “Guide de } \\
\text { consommation du } \\
\text { poisson de pêche } \\
\text { sportive en eau douce," } \\
\text { n.d.) } \\
\end{array}$ \\
\hline New Brunswick & \begin{tabular}{|l|} 
New Brunswick \\
Department of Natural \\
Resources and Energy; New \\
Brunswick Health and \\
Wellness; New Brunswick \\
Ministry of Environment \\
and Local Government; \\
Department of Fisheries \\
and Oceans \\
\end{tabular} & $\begin{array}{l}\text { https://www2.gnb.ca/cont } \\
\text { ent/gnb/en/departments/ } \\
\text { erd/natural_resources/con } \\
\text { tent/fish/content/Mercury } \\
\text { InFish.html (accessed Oct } \\
\text { 2019) }\end{array}$ & $\begin{array}{l}\text { mercury** (M. E. Wood } \\
\text { 2001) }\end{array}$ \\
\hline
\end{tabular}




\begin{tabular}{|c|c|c|c|}
\hline Nova Scotia & $\begin{array}{l}\text { Nova Scotia Department of } \\
\text { Health; Nova Scotia } \\
\text { Department of } \\
\text { Environment and Labour; } \\
\text { Nova Scotia Department of } \\
\text { Fisheries and Aquaculture; } \\
\text { Department of Fisheries } \\
\text { and Oceans; Environment } \\
\text { Canada; Nova Scotia } \\
\text { Department of Agriculture } \\
\text { and Fisheries }\end{array}$ & $\begin{array}{l}\text { https://novascotia.ca/nse/ } \\
\text { fish-consumption-advisory. } \\
\text { asp (accessed Mar 23, } \\
\text { 2020) }\end{array}$ & $\begin{array}{l}\text { mercury*, PCBs* ("Fish } \\
\text { Consumption Advisory" } \\
\text { n.d.) }\end{array}$ \\
\hline Prince Edward Island & \begin{tabular}{|l|} 
Prince Edward Island \\
Department of Fisheries, \\
Aquaculture, and \\
Environment; Prince \\
Edward Island Department \\
of Health and Wellness
\end{tabular} & $\begin{array}{l}\text { https://www.princeedwar } \\
\text { disland.ca/en/information } \\
\text { /environment-water-and-c } \\
\text { limate-change/angling-res } \\
\text { ources-and-information-ce } \\
\text { ntre (accessed Mar 23, } \\
\text { 2020) }\end{array}$ & $\begin{array}{l}\text { Mercury (M. E. Wood } \\
2001 \text { ) }\end{array}$ \\
\hline Newfoundland & $\begin{array}{l}\text { Department of Fisheries } \\
\text { and Oceans; Newfoundland } \\
\text { and Labrador Hydro; } \\
\text { Newfoundland and } \\
\text { Labrador Department of } \\
\text { Environment and Climate } \\
\text { Change }\end{array}$ & $\begin{array}{l}\text { http://ec.gc.ca/mercure-m } \\
\text { ercury/default.asp?lang=E } \\
\text { n\&n=DCBE5083-97AD-4C } \\
\text { 62-8862\#NF (accessed } \\
\text { Mar 23, 2020) }\end{array}$ & $\begin{array}{l}\text { Mercury ("Mercury } \\
\text { Program" n.d.) }\end{array}$ \\
\hline Yukon & $\begin{array}{l}\text { Government of Yukon; } \\
\text { Department of Indian } \\
\text { Affairs and Northwest } \\
\text { Development; Yukon } \\
\text { Government Department of } \\
\text { Health; Yukon Government } \\
\text { Health and Social Services; } \\
\text { Yukon Government } \\
\text { Renewable Resources; } \\
\text { Yukon Contaminants } \\
\text { Committee }\end{array}$ & $\begin{array}{l}\text { https://yukon.ca/yukon-fi } \\
\text { sh-health-handbook } \\
\text { (accessed Mar 23, 2020) }\end{array}$ & $\begin{array}{l}\text { Mercury ("Yukon Fish } \\
\text { Health Handbook" } \\
\text { 2014) }\end{array}$ \\
\hline Northwest Territories & $\begin{array}{l}\text { Department of Fisheries } \\
\text { and Oceans; Northwest } \\
\text { Territories Environmental } \\
\text { Contaminants Committee; } \\
\text { Government of Northwest } \\
\text { Territories Health and } \\
\text { Social Services; } \\
\text { Department of Indian } \\
\text { Affairs and Northern } \\
\text { Development }\end{array}$ & $\begin{array}{l}\text { https://www.hss.gov.nt.ca } \\
\text { /en/services/recommanda } \\
\text { tions-sur-la-consommation } \\
\text {-de-poisson/site-specific-fi } \\
\text { sh-consumption-advice } \\
\text { (accessed Mar 23, 2020) }\end{array}$ & $\begin{array}{l}\text { mercury, PCBs, DDT, } \\
\text { PBDEs, organohalogens } \\
\text { (“NWT Fish } \\
\text { Consumption Notices" } \\
\text { n.d.) }\end{array}$ \\
\hline
\end{tabular}


Nunavut

Nunavut has no fish
consumption advisory
program in place (M. E.
Wood 2001)

*Contaminant is only tested based on specific studies suggesting pollution of specific waterbodies and/or fish species (or is simply done by choice), rather than being tested routinely throughout the region.

**No active testing for contaminants. All fish consumption advisories based on past testing.

Appendix C: House Bill 2859 concerning increased fish tissue monitoring in Arizona presented during the fifty-fourth session of the Arizona State Legislature.

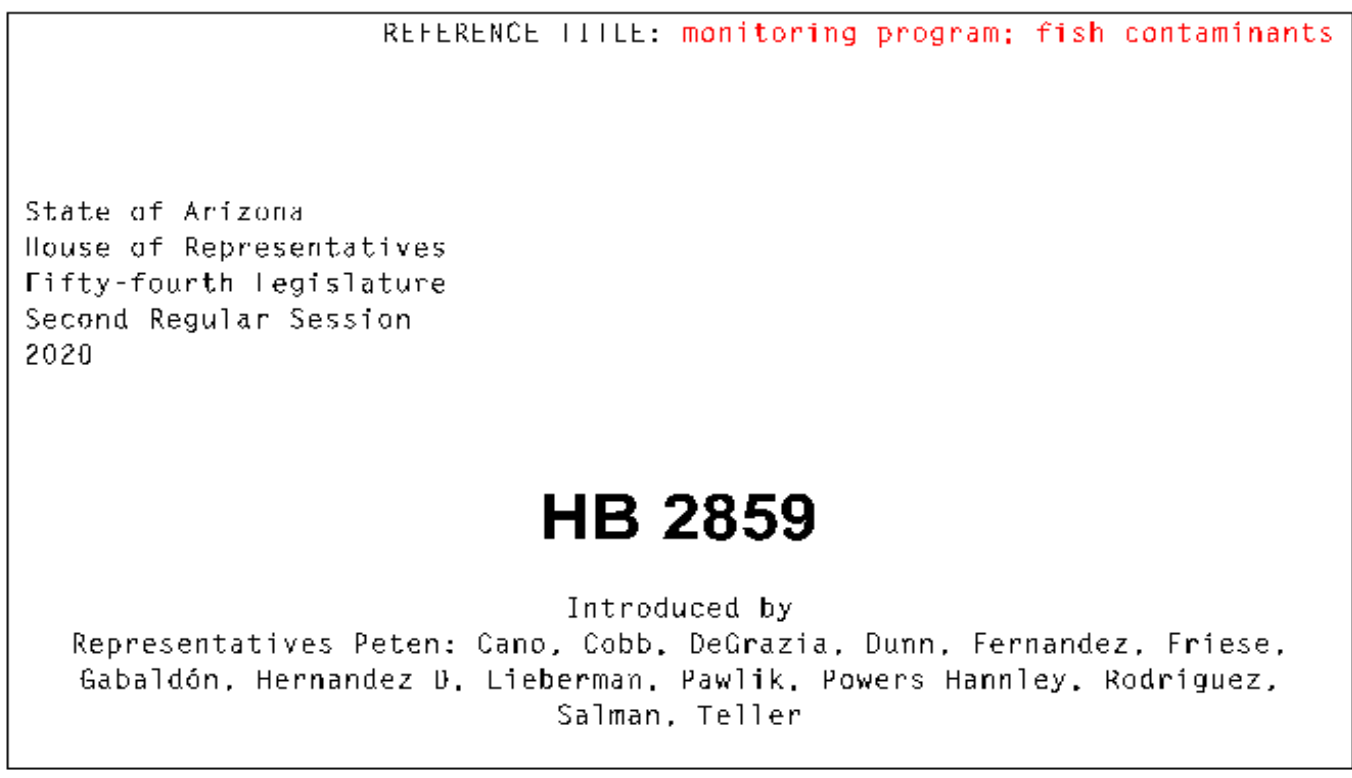

AN ACT

AMENDING TITLE 49, GHAPTER 2. ARticle 1. ARIZONA REUised Statutes, by ADDING SECTION 49-210.01: APPROPRIATING MONIES; RELATING TO WATER QUALITY CONTROL.

(TEXT OF BILL BEGINS ON NEXT PAGE) 
HB 2859

Be it enacted by the Legislature of the State of Arizona:
Section 1. Title 49. chapter 2, article 1, Arizona Revised
Statutes, is anended by adding section $49-210.01$, to read:
$49-210.01$. Fish contaminant monitoring oroaram: health
assessments: remination: definition
A. THE DEPARTMENT SHALL DEVELOP A COMPREHENSIVE WATER QUALITY MONITORING AND ASSESSMENT PROGRAM FOR THE EVALUATION OF POLYCHLORINATED BIPHENYLS, PESTICIDES, METALS AND OTHER CONTAMINANTS OF CONCERN IN SPORT FISH AS PART OF THE FISH CONTAMINANT MONITORING PROGRAM. THE PROGRAM SHALL IDENTIFY AND MONITOR CHEMICAL CONTAMINATION IN SPORT FISH AND ASSESS THE HEALTH RISKS OF CONSUMPTION OF SPORT FISH CAUGHT BY MEMBERS OF THE PUBLIC.

B. THE DEPARTMENT OF ENVIRONMENTAL QUALITY SHALL CONSULT WITH THE ARIZONA GAME AND FISH DEPARTMENT, THE UNITED STATES ENVIRONMENTAL PROTECTION AGENCY AND LOCAL OR REGIONAL POLITICAL SUBDIVISIONS OR PRIVATE ENTITIES WITH JURISDICTION OVER WATER BODIES TO DETERMINE ACCEPTABLE CONTAMINANT THRESHOLDS, PROTOCOLS FOR SELECTING SAMPLING LOCATIONS, SAMPLING FREQUENCY AND NUMBER AND TYPE OF SPECIES TO BE MONITORED UNDER THE PROGRAM. THE PROGRAM DEVELOPED BY THE DEPARTMENT SHALL INCLUDE ALL OF THE FOLLONING:

1. SAMPLING AND ANALYZING FISH FROM ALL WATERS IN THIS STATE THAT SUPPORT RECREATIONAL FISHERIES FOR POLYCHLORINATED BIPHENYLS, PESTICIDES AND METALS WITHOUT REGARD TO THE WATER BODY'S DESIGNATION UNDER THE CLEAN WATER ACT, WITH A SPECIAL EMPHASIS ON MONITORING WATER AND FISH IN URBAN AREAS.

2. CONDUCTING THE SAMPLING AND MONITORING OF FISH AS PRESCRIBED BY PARAGRAPH 1 OF THIS SUBSECTION AT EACH SITE AT LEAST ONCE EVERY THREE YEARS AS PART OF THE ENVIRONMENTAL PROTECTION AGENCY TRIENNIAL WATER QUALITY REVIEWS.

3. CONDUCTING ANNUAL SCREENINGS TO IDENTIFY NEW AQUATIC AREAS WHERE FISH HAVE THE POTENTIAL FOR ACCUMULATING CONTAMINANTS THAT CAN POSE SIGNIFICANT RISKS TO ECOSYSTEMS AND HUMAN HEALTH. SCREENING SITES THAT SHOW CONTAMINANT LEVELS OF POTENTIAL CONCERN SHALL BE REASSESSED AT LEAST ONCE EVERY THREE YEARS.

C. THE DEPARTMENT OF ENVIRONMENTAL QUALITY SHALL CONTRACT WITH THE DEPARTMENT OF HEALTH SERVICES TO PREPARE COMPREHENSIVE HEALTH RISK ASSESSMENTS FOR SPORT FISH MONITORED IN THE PROGRAM AS FOLLOWS:

1. THE ASSESSMENTS SHALL BE BASED ON THE DATA COLLECTED BY THE PROGRAM AND INFORMATION ON FISH CONSUMPTION AND FOOD PREPARATION.

2. AFTER EACH TRIENNIAL WATER QUALITY REVIEW, THE DEPARTMENT OF ENVIRONMENTAL QUALITY SHALL SUBHIT A HEALTH RISK ASSESSMENT REPORT FOR THIS STATE'S FISHERIES TO THE ARIZONA WATER PROTECTION FUND COMMISSION ESTABLISHED BY SECTION 45-2103 AND THE ARIZONA GAME AND FISH COMMISSION. 
HB 2859

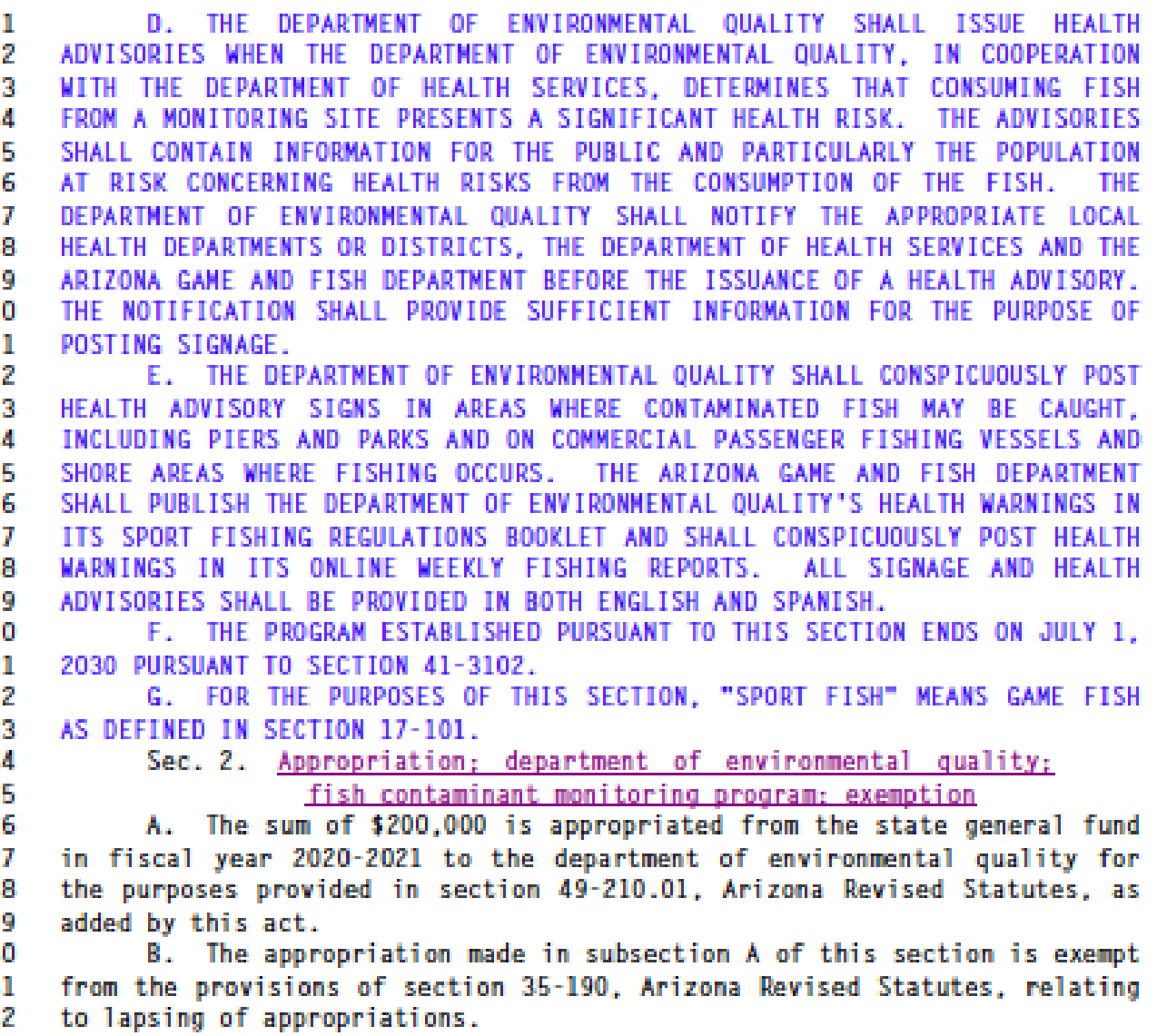

\section{References}

2018 Fish Smart, Eat Smart." n.d. New Jersey Department of Environmental Protection and New Jersey

Department of Health. 
https://www.ni.gov/dep/dsr/Fish Advisories 20 18.pdf.

2020 Community Fishing Guidebook." n.d. https://s3-us-west-2.amazonaws.com/azgfd-port al-wordpress-pantheon/wp-content/uploads/arc hive/2020-CFP-Guidebook-SP.pdf

2020 Missouri Fish Advisory: A Guide to Eating Missouri Fish." n.d. Missouri Department of Health and Senior Services. https://health.mo.gov/living/environment/fisha dvisory/pdf/fishadvisory.pdf

About Chemicals and Bacteria in Fish and Additional Information." n.d. New York State Department of Health. Accessed March 23, 2020. https://www.health.ny.gov/environmental/outd oors/fish/health advisories/additional informati on.htm.

Alabama Department of Environmental Management Fish Tissue Monitoring Program." 2007. https://www.alabamapublichealth.gov/tox/asset s/fishtissuemonitoring.pdf.

Ambient Fish and Turtle Tissue Monitoring." n.d. Iowa Department of Natural Resources. Accessed March 23, 2020. https://www.iowadnr.gov/Environmental-Protec $\underline{\text { tion/Water-Quality/Water-Monitoring/Fish-Tissu }}$ e.

Arizona Game and Fish Department 2015-2016 Annual Report." n.d. Annual Report. Arizona Game and Fish

Department. https://s3.amazonaws.com/azgfd-portal-wordpr ess/azgfd.wp/wp-content/uploads/2017/09/01 113159/AZGFD-Annual-Report FY2015-16 FINA L.pdf.

Bill C-69. 2019. Vol. Statutes of Canada 2019. https://www.parl.ca/DocumentViewer/en/42-1/ bill/C-69/royal-assent.

CBC News. 2015. "Mercury Levels Curb Fish Consumption in Jean Marie River, N.W.T.," November 1, 2015.

CBC News. 2019. "Singh Commits to Lift All Drinking Water Advisories in Indigenous Communities by 2021," October 5, 2019.

Contaminants and Health Risks." n.d. West Virginia Fish Consumption Advisories. Accessed March 23, 2020.

http://www.wvdhhr.org/fish/General Advisories .asp.

Contaminants in Fish." n.d. Indiana State Department of Health. Accessed March 23, 2020a. https://www.in.gov/isdh/26877.htm.

Contaminants in Fish." n.d. Washington State Department of Health. Accessed March 23, 2020. https://www.doh.wa.gov/CommunityandEnviron ment/Food/Fish/ContaminantsinFish.
CT Fish Consumption Advisory and the Safe Eating of Fish Caught in Connecticut." n.d. Connecticut State Department of Public Health. Accessed March 23, 2020.

https://portal.ct.gov/DPH/Environmental-Health EEnvironmental-and-Occupational-Health-Assess ment/CT-Fish-Consumption-Advisory-and-the-Sa fe-Eating-of-Fish-Caught-in-Connecticut.

Delaware 2018 Fish Consumption Advisory Data." n.d. http://www.dnrec.delaware.gov/Admin/Docume nts/2018-Delaware-fish-consumption-advisory-d ata.pdf.

Eating Fish Safely in Massachusetts." n.d. Mass.Gov. Accessed March 23, 2020. https://www.mass.gov/info-details/eating-fish-s afely-in-massachusetts.

Environmental and Public Health Information." n.d. Oklahoma Department of Environmental Quality. https://www.deq.ok.gov/state-environmental-la boratory-services/environmental-public-health-i nformation/.

Environmental Justice." n.d. Environmental Justice. Accessed March 23, 2020. https://www.epa.gov/environmentaljustice.

Fairclough, Ian. 2019. "NS Fishers Info." The Chronicle Herald, March 15, 2019. https://www.thechronicleherald.ca/news/local/ more-standardized-angling-rules-floated-in-nova -scotia-292336/.

Federal Pollution Control Act. 2002. USC. Vol. 33.

"Fish." n.d.

CA.Gov. https://oehha.ca.gov/fish.

"Fish Advisories." n.d. Arkansas Department of Health. Accessed March 23, 2020. https://www.healthy.arkansas.gov/programs-ser vices/topics/fish-advisories.

Fish Advisories in Illinois." n.d. Illinois Department of Public Health. Accessed March 23, 2020. http://www.idph.state.il.us/envhealth/factsheets ffishadv.htm.

Fish Advisory Program." n.d. Hawai'i Health Matters. Accessed March 23, 2020. http://www.hawaiihealthmatters.org/promisepr actice/index/view?pid=447.

Fish Consumption." n.d. Pennsylvania Department of Environmental Protection. https://www.dep.pa.gov/Business/Water/Clean Water/WaterQuality/FishConsumptionAdvisory/ Pages/default.aspx.

Fish Consumption Advice." n.d. Wyoming Game and Fish Department.

https://wgfd.wyo.gov/Fishing-and-Boating/FishConsumption-Advice/.

Fish Consumption Advisories." n.d. Kentucky Department 
of Fish and Wildlife. Accessed March 23, 2020. https://fw.ky.gov/Fish/Pages/Fish-Consumption -Advisories.aspx.

Fish Consumption Advisories." n.d. North Carolina Department of Health and Human Services. https://epi.publichealth.nc.gov/oee/fish/advisor ies.html.

Fish Consumption Advisory." n.d. Maine Department of Inland Fisheries and Wildlife. https://www.maine.gov/ifw/fishing-boating/fish ing/laws-rules/consumption-advisory.html.

Fish Consumption Advisory." n.d. My Wild Alberta. https://mywildalberta.ca/fishing/advisories-corr ections-closures/fish-consumption-advisory.aspx.

Fish Consumption Advisory." n.d. Nova Scotia Environment. Accessed March 23, 2020. https://novascotia.ca/nse/fish-consumption-adv isory.asp.

Fish Consumption Advisory for Waters of North Dakota." 2001. North Dakota Department of Health. http://www.library.nd.gov/statedocs/Health/B F ishAdvisory.pdf.

Fish Consumption Advisory Standard Operating Guidance (SOG) Oregon Health Authority (OHA) Fish Advisory Program." 2018. Oregon Health Authority.

https://www.oregon.gov/oha/PH/HEALTHYENV IRONMENTS/RECREATION/FISHCONSUMPTION Documents/Fish-Consumption-Advisory-SOG.pd f.

Fish Consumption Program Summary." n.d. Colorado Department of Public Health and Environment. https://www.colorado.gov/pacific/cdphe/wq-fis h-consumption-program-summary.

Fish Consumption Safety." n.d. Nevada Department of Wildlife.

http://www.ndow.org/Fish/Fish Safety.

Fish Facts and Consumption Guidelines." n.d. Alaska Department of Health and Social Services. http://dhss.alaska.gov/dph/Epi/eph/Pages/fish/ default.aspx\#facts.

Fish Is Good, Mercury Is Bad." n.d. Rhode Island Department of Health. http://www.health.ri.gov/publications/brochure s/FishIsGoodMercuryIsBad.pdf.

Fish Tissue Contaminant Monitoring Program." n.d. Kansas Department of Health and Environment. http://www.kdheks.gov/befs/fish tissue monito ring.htm.

Fish Tissue Monitoring Program." n.d. Nebraska Department of Environment and Energy. http://deq.ne.gov/NDEQProg.nsf/OnWeb/FTMP.

Fishing Consumption and Swimming Advisories." n.d. Louisiana Department of Environmental Quality. Accessed March 23, 2020. https://deq.louisiana.gov/index.cfm?md=pagebu ilder\&tmp=home\&pid=fishing-consumption-andswimming-advisories.

Fishing License Renewals and Angler Lifestyles." 2016. Final Report. American Sportfishing Association. https://www.southwickassociates.com/wp-conte nt/uploads/downloads/2017/03/Summary-Pres entation-Fishing-License-Renewals-and-Angler-L ifestyles-3-6-17.pdf.

Frequently Asked Questions about Polychlorinated Biphenyls (PCBs) and Mercury Fish Consumption Advisories in Virginia Waters." n.d. Virginia Department of Health. http://www.vdh.virginia.gov/content/uploads/si tes/12/2016/01/Fish-Consumption-Advisory-Fa ct-Sheet-2016.pdf.

General Information on the Risk of Eating Fish - Seafood and Aquatic Life." n.d. Texas Department of State Health Services. Accessed March 23, 2020. https://www.dshs.texas.gov/seafood/risks-of-eat ing-fish.aspx\#contaminants.

Guidance for Assessing Chemical Contaminant Data for Use in Fish Advisories." 1995. US Environmental Protection Agency. https://www.epa.gov/sites/production/files/20 18-11/documents/guidance-assess-chemical-con taminant-vol4.pdf.

Guide de consommation du poisson de pêche sportive en eau douce." n.d. Environnement et Lutte contre les changements climatiques Québec. http://www.environnement.gouv.qc.ca/eau/guid e/localisation.asp.

Guidelines For Eating Fish From Georgia Waters." 2018. Georgia Department of Natural Resources. https://epd.georgia.gov/sites/epd.georgia.gov/fil es/related files/site page/FCG 2018102618 PR INT EAB\%20review.pdf.

Hamilton, C. 2010. "Why We Resist the Truth about Climate Change." Climate Controversies: Science and Politics.

Health Alert." 2013. Vermont Department of Health. http://www.healthvermont.gov/sites/default/fil es/documents/2016/11/Env RW mercury fish a lert.pdf.

Idaho Fish Consumption Advisory Project Protocol." n.d. Idaho Department of Health and Welfare, Bureau of Community and Environmental Health. https://healthandwelfare.idaho.gov/Portals/0/H ealth/EnvironmentalHealth/IFCAP PROTOCOL.p df.

LeBlanc, J.E., and E.A. Halfyard. 2010. "Mercury and Arsenic Concentrations in Fish Tissues and the Influence of Historic Gold Mines in Nova Scotia." Nova Scotia Department of Fisheries and Aquaculture. 
https://novascotia.ca/fish/documents/special-m anagement-areas-reports/Mercury-Arsenic-in-fis h.pdf.

License." n.d. Arizona Game and Fish Department. Accessed March 23, 2020. https://www.azgfd.com/license/.

Lower Duwamish Waterway Seattle, WA." n.d. United States Environmental Protection Agency. https://cumulis.epa.gov/supercpad/SiteProfiles/ index.cfm? fuseaction $=$ second.Cleanup\&id $=10020$ 20\#bkground.

Lucas, Daniel, and Beth Polidoro. 2019. "Urban Recreational Fisheries: Implications for Public Health in Metro-Phoenix." Chemosphere 225 (June): 451-59.

Map: Guide to Eating Ontario Fish." n.d. https://www.ontario.ca/environment-and-energ v/eating-ontario-fish.

MDE Fish Consumption Advisory." n.d. Maryland.Gov. https://mde.maryland.gov/programs/Marylande r/fishandshellfish/Pages/fishconsumptionadviso ry.aspx.

Mercury in Fish." n.d. https://www.gov.mb.ca/sd/waterstewardship/re ports/mercury in fish.pdf.

Mercury in Saskatchewan Fish: Guidelines for Consumption Updated to 2015." n.d. http://www.environment.gov.sk.ca/Default.aspx? DN=90437caa-287b-4fa1-9217-8f5e5de1ad34.

Mercury Program." n.d. Newfoundland and Labrador Municipal Affairs and Environment. Accessed March 23, 2020. https://www.mae.gov.nl.ca/env protection/scien ce/mercury.html.

Mercury: Your Health and the Environment." 2004. Health Canada Mercury Issues Task Group. https://www.canada.ca/content/dam/hc-sc/mig ration/hc-sc/ewh-semt/alt formats/hecs-sesc/p df/pubs/contaminants/mercury/mercur-eng.pdf.

Minnesota's Fish Contaminant Monitoring Program." 2008. Minnesota Pollution Control Agency, Minnesota Department of Health, Minnesota Department of Natural Resources. https://www.pca.state.mn.us/sites/default/files/ p-p2s4-05.pdf.

Montana Sport Fish Consumption Guidelines." n.d. fwp.mt.gov/fwpDoc.html?id=28187.

New Mexico Fish Consumption Advisories." 2012. New Mexico Department of Game and Fish, New Mexico Department of Health, New Mexico Environment Department. https://www.epa.gov/sites/production/files/20 15-10/documents/fish consumption.pdf.

Nova Scotia Mining Operations (2018)." 2019. Nova Scotia Department of Energy and Mines. https://novascotia.ca/natr/meb/data/mg/ofi/pd f/ofi 2019-001.pdf.

NS Fish Consumption Advisories." n.d. Fish Consumption Advisory. Accessed September 9, 2019. https://novascotia.ca/nse/fish-consumption-adv isory.asp.

Nunavut FAQs." n.d. Nunavut FAQs. Accessed February 24, 2020.

https://www.gov.nu.ca/eia/information/nunavut -faqs.

NWT Fish Consumption Notices." n.d. ArcGIS Map. http://www.arcgis.com/home/webmap/viewer.h tml?webmap $=7199 \mathrm{~b} 8175$ dac48dc8513c824e39a a3fd\&extent $=-125.8875,60.1396,-102.1131,66.88$ $\underline{55}$.

PFAS in Fish." n.d. Michigan.Gov. Accessed March 23, 2020. https://www.michigan.gov/pfasresponse/0,9038

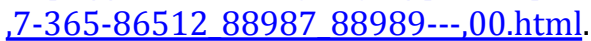

Ponting, Clive. 2007. A New Green History of the World. Great Britain: Penguin Books.

Roe, A. 2003. "Fishing for Identity: Mercury Contamination and Fish Consumption among Indigenous Groups in the United States." Bulletin of Science, Technology, and Society 23 (5): 368-75.

Schrank, Candy. n.d. "Wisconsin's Fish Contaminant Monitoring and Advisory Program: 1970-2010." Administrative Report 73. Madison, Wisconsin: Wisconsin Department of Natural Resources. https://dnr.wi.gov/topic/fishing/documents/pub lications/AdminReport73.pdf.

Search Water Quality Data." n.d. Arizona Department of Environmental Quality. Accessed October 19, 2020.

https://waterdata.azdeq.gov/AZWQDB/Pages/P ublic/.

Silver, Elena, Jessica Kaslow, Diana Lee, Sun Lee, May Lynn Tan, Erica Weis, and Alyce Ujihara. 2007. "Fish Consumption and Advisory Awareness among Low-Income Women in California's Sacramento-San Joaquin Delta." Environmental Research 104 (3): 410-19.

South Dakota Fish Consumption Advisories." n.d. South Dakota Department of Health. https://doh.sd.gov/food/SDadvisories.aspx.

State of Mississippi Water Quality Assessment 2018 Section 305(b) Report." 2018. Jackson, Mississippi: Mississippi Department of Environmental Quality. https://www.mdeq.ms.gov/wp-content/uploads 2019/01/2018 305bReport Final-002.pdf.

State of Ohio Cooperative Fish Tissue Monitoring Program Fish Tissue Environmental Assessment Program." $2005 . \quad$ Final Report. https://www.epa.ohio.gov/portals/35/fishadviso ry/FishTissueEnvAssessProg05v2.pdf. 
Summary of Executive Order 12898 - Federal Actions to Address Environmental Justice in Minority Populations and Low-Income Populations." n.d. United States Environmental Protection Agency. Accessed March 23, 2020. https://www.epa.gov/laws-regulations/summar y-executive-order-12898-federal-actions-address -environmental-justice.

Survey of Recreational Fishing in Canada, 2015." 2019. Fisheries and Oceans Canada. https://www.dfo-mpo.gc.ca/stats/rec/can/2015 Ldoc/2015-rec-fish-eng.pdf.

Tan, Mary Lynn, Alyce Ujihara, and Ilinisia Hendrickson. 2011. "Communicating Fish Consumption Advisories in California: What Works, What Doesn't." Risk Analysis 31 (7): 1095-1106.

Tasker, John Paul. 2019. "Trudeau Extends Olive Branch to Western Canada, Vows to Build Trans Mountain despite Opposition." Canadian Broadcast Corporation, October 23, 2019. https://www.cbc.ca/news/politics/trudeau-west ern-canada-trans-mountain-1.5332365.

Terry, Ana, Kirsten Herrick, Joseph Afful, and Namanjeet Ahluwalia. 2018. "Seafood Consumption in the United States, 2013-2016." Data Brief 321. National Center for Health Statistics. https://www.cdc.gov/nchs/data/databriefs/db3 21.pdf.

Tilden, J., L. P. Hanrahan, H. Anderson, C. Palit, J. Olson, and W. M. Kenzie. 1997. "Health Advisories for Consumers of Great Lakes Sport Fish: Is the Message Being Received?" Environmental Health Perspectives 105 (12): 1360-65.

TN Fishing Guide 2018-2019." 2018. Issuu. February 8, 2018.

https://issuu.com/thebinghamgroup/docs/twraf ishing2018 interactive/36.

Tutton, Michael. 2020. "N.S. Judge Agrees with Mi'kmaq Band, Requires Further Talks on Alton Gas Project." CTV News, March 24, 2020. https://atlantic.ctvnews.ca/n-s-judge-agrees-wit h-mi-kmaq-band-requires-further-talks-on-altongas-project-1.4866350.

Utah Fish Advisories." n.d. Utah Department of Environmental Quality. https://deq.utah.gov/fish-advisories/utah-fish-a dvisories.

What Are Fish Consumption Advisories?" n.d. South Carolina Department of Health and Environmental Control.

https://www.scdhec.gov/food-safety/food-monit oring-advisories/fish-consumption-advisories/w hat-are-fish-consumption.

Wildlife and Birds of Nova Scotia." n.d. Government of Nova Scotia. Accessed February 25, 2020. https://novascotia.ca/natr/wildlife/wns/wns7e. asp.

Willick, Frances. 2020. "Impact of Gold Mine Contamination in N.S. Understudied, Research Finds." CBC News, February 25, 2020.

Wood, M. E. 2001. "Examining Fish Consumption Advisories Related to Mercury Contamination in Canada."

Wood, Matthew, and Ken Edwardson. 2020. "2018 Section 305(b) and 303(d) Consolidated Assessment and Listing Methodology." R-WD-19-04. New Hampshire Department of Environmental Services.

https://www.des.nh.gov/organization/divisions/ water/wmb/swqa/2018/documents/r-wd-19-04 .pdf.

"Your Guide To Eating Fish Caught In Florida." 2018. Florida Department of Health. http://www.floridahealth.gov/programs-and-ser vices/prevention/healthy-weight/nutrition/seaf ood-consumption/documents/advisory-brochur e.pdf.

"Yukon Fish Health Handbook." 2014. Yukon Department of the Environment. https://yukon.ca/sites/yukon.ca/files/env/env-y ukon-fish-health-handbook.pdf.

Rachael King is an MA student at the Virginia Institute of Marine Science through the College of William and Mary. She completed her BS in Environmental Science at Arizona State University, where she conducted research on fish consumption advisory programs across the US and Canada. She traveled to Nova Scotia for the Canadian arm of her research through a Fulbright Canada grant. She has presented legislation in the Arizona State Legislature during multiple sessions. She has also worked as an educator with Arizona Project WET. She plans to pursue a career in science policy, with an emphasis on environmental toxicology. 
Beth Polidoro is an Associate Professor of Environmental Chemistry and Marine Conservation in the School of Mathematical and Natural Sciences at Arizona State University. She is the Associate Director of ASU's Center for Biodiversity Outcomes, and is co-Chair of the International Union for the Conservation of Nature (IUCN)'s Species Survival Commissions' Marine Fishes and Reef-Building Corals specialist groups. Her research interests are in risk assessment and applied toxicology within the context of marine and freshwater biodiversity conservation, environmental pollution, human health and sustainable development. Currently, she works on various environmental conservation initiatives and risk assessments in southeast Asia, Latin America, Africa and Oceania.

Karen Watanabe is an Associate Professor in the School of Mathematical and Natural Sciences at Arizona State University. She is currently the program lead for the Pharmacology and Toxicology Bachelor's degree, and interim director for the Biological Data Science Master's degree. Her research focuses on developing biologically based mathematical models of how chemicals in the environment affect living organisms, and using probabilistic methods to capture biological uncertainty and variability in model predictions for toxicology and risk assessment. She is passionate about creating educational bridges between the life sciences and mathematical/computational sciences, and providing innovative work-based learning opportunities for students at all levels.

Trevor Avery is an Associate Professor cross-appointed to Biology and Mathematics \& Statistics at Acadia University. His research interests are in fish and fisheries, animal movements, and population dynamics. He works with students on projects to improve our understanding of fish and fisheries through monitoring programs. Many projects involve tagging fish and lobster for capture-mark-recapture, and sampling fish for various fish health indicators such as contaminants, and include community-driven or citizen science initiatives. His research group curates data on many fish species across large areas to help inform fisheries and conservation activities and management through understanding of fish biology and population dynamics.

\section{Acknowledgements}

The authors would like to acknowledge the NCUIRE program at Arizona State University West and Fulbright Canada's Killam Fellowship for providing necessary funding to this research. The authors would also like to thank ADEQ for their cooperation with this research and Senator Mendez and Representative Peten for supporting legislation presented as a result of this research. 